Review Article

\title{
Natural Products with Inhibitory Activity against Human Immunodeficiency Virus Type 1
}

\author{
Maria S. Serna-Arbeláez $\mathbb{D}^{1,2}$ Laura Florez-Sampedro, ${ }^{3}$ Lina P. Orozco, ${ }^{3}$ \\ Katherin Ramírez, ${ }^{3}$ Elkin Galeano $\mathbb{D}^{\mathbb{D}},{ }^{4}$ and Wildeman Zapata $\mathbb{D}^{1,3}$ \\ ${ }^{1}$ Grupo Infettare, Facultad de Medicina, Universidad Cooperativa de Colombia, Medellín, Colombia \\ ${ }^{2}$ Grupo de Investigacion en Ciencias Animales-GRICA, Facultad de Medicina Veterinaria y Zootecnia, \\ Universidad Cooperativa de Colombia, Bucaramanga, Colombia \\ ${ }^{3}$ Grupo Inmunovirología, Facultad de Medicina, Universidad de Antioquia (UdeA), Medellín, Colombia \\ ${ }^{4}$ Productos Naturales Marinos, Departamento de Farmacia, Facultad de Ciencias Farmacéuticas y Alimentarias, \\ Universidad de Antioquia (UdeA), Medellín, Colombia
}

Correspondence should be addressed to Wildeman Zapata; wildeman.zapatab@campusucc.edu.co

Received 19 January 2021; Accepted 19 May 2021; Published 30 May 2021

Academic Editor: Jay C. Brown

Copyright (C) 2021 Maria S. Serna-Arbeláez et al. This is an open access article distributed under the Creative Commons Attribution License, which permits unrestricted use, distribution, and reproduction in any medium, provided the original work is properly cited.

Infections caused by human immunodeficiency virus (HIV) are considered one of the main public health problems worldwide. Antiretroviral therapy (ART) is the current modality of treatment for HIV-1 infection. It comprises the combined use of several drugs and can decrease the viral load and increase the $\mathrm{CD} 4^{+}$T cell count in patients with HIV-1 infection, thereby proving to be an effective modality. This therapy significantly decreases the rate of morbidity and mortality owing to acquired immunodeficiency syndrome (AIDS) and prolongs and improves the quality of life of infected patients. However, nonadherence to ART may increase viral resistance to antiretroviral drugs and transmission of drug-resistant strains of HIV. Therefore, it is necessary to continue research for compounds with anti-HIV-1 activity, exhibiting a potential for the development of an alternative or complementary therapy to ART with low cost and fewer side effects. Natural products and their derivatives represent an excellent option owing to their therapeutic potential against HIV. Currently, the derivatives of natural products available as anti-HIV-1 agents include zidovudine, an arabinonucleoside derivative of the Caribbean marine sponge (Tectitethya crypta), which inhibits the reverse transcriptase of the virus. This was the first antiviral agent approved for treatment of HIV infection. Additionally, bevirimat (isolated from Syzygium claviflorum) and calanolide A (isolated from Calophyllum sp.) are inhibitors of viral maturation and reverse transcription process, respectively. In the present review, we aimed to describe the wide repertoire of natural compounds exhibiting anti-HIV-1 activity that can be considered for designing new therapeutic strategies to curb the HIV pandemic.

\section{Introduction}

Since the emergence of the human immunodeficiency virus (HIV) and with time, the pandemic caused by this virus has been established as one of the main public health problems worldwide, generating new challenges in terms of its prevention and control [1]. Currently, approximately 38 million people are infected with the virus, of which around 32\% are not receiving antiretroviral treatment; 1.7 million individuals were newly infected in 2019, and an average of 690.000 deaths occur each year from acquired immunodeficiency syndrome (AIDS)-related diseases [2].
The complex and successful life cycle of HIV prevents its natural removal from the host mediated by the immune system [3]. The action of viral proteins is essential during the HIV replication cycle; these proteins include reverse transcriptase (RT), which synthesizes double-stranded DNA from single-stranded viral RNA, a fundamental step for viral replication; protease, which processes viral polyproteins and converts them into functional proteins; gp120 and gp41 glycoproteins, which facilitate the fusion of the viral membrane with the host cell membrane; and integrase, which mediates viral genome integration within the host DNA $[3,4]$. 
These proteins are fundamental in the pathogenesis of HIV and represent the main targets of antiretroviral therapy (ART), which generally include three active drugs from two or more drug classes [5]. This is currently considered the standard treatment for HIV infection [6] and has radically changed the prognosis of HIV infection because ART can reduce the viral load, increases the CD4+ T cells count, and reduces the probability of new opportunistic infections, thereby significantly lowering the morbidity and mortality of AIDS and extending the life of infected individuals [7-9]. However, specific issues are associated with the use of ART, including limited access to medications and various side effects associated with their use, such as lipodystrophy and metabolic disturbances associated with protease inhibitors (PIs), hypersensitivity and hepatotoxicity due to nucleoside reverse transcriptase inhibitors (NRTIs), and mitochondrial toxicity related to non-nucleoside reverse transcriptase inhibitors (NNRTIs) [10, 11], which decrease treatment adherence, favoring the emergence of some viral strains resistant to therapy [12-15]. Since $68 \%$ of the expenses incurred by the healthcare system for the medical attention of a person with HIV correspond to antiviral drugs [16], research is ongoing for new compounds or molecules capable of significantly inhibiting viral replication-with few or no side effects-that can be developed as therapeutic agents and become easily accessible worldwide [17-19].

Natural products have garnered special interest because of the existing biodiversity of flora worldwide and the ease of obtaining extracts and crude forms from these sources with the help of technological innovation [17]. Therefore, it is important to know the wide repertoire of natural compounds exhibiting anti-HIV activity, considering that their identification is essential for designing new therapeutic strategies to counteract the morbidity and mortality associated with the HIV-1 pandemic.

Owing to the great variety of compounds that may be found, the concentration of drug required for $50 \%$ inhibition $\left(\mathrm{IC}_{50}\right)$ and selectivity index (SI) of each compound must be particularly considered. SI indicates the number of times that the $\mathrm{IC}_{50}$ must increase to achieve a cytotoxic effect of $50 \%$, which means that the compounds considered having therapeutic potential are those with SI of $\geq 10$ [20].

This work aimed to review some of the main natural compounds with anti-HIV activity that have been purified or derived from fungi, plants, and marine sponges and to describe their possible mechanisms of inhibition of HIV-1 replication. Considering that there is a wide range of natural compounds with potential anti-HIV activity, we mainly focused on terpenes, coumarins, flavonoids, laccases, lectins, ribosome-inactivating proteins (RIPs), and bromotyrosines (Figure 1).

\section{Terpenes}

Terpenes are secondary metabolites synthesized by plants, fungi, and animals. They are classified based on the number of isoprene units (C5) present in their chemical structure [21]. Different types of terpenes exhibiting anti-HIV activities include monoterpenes, diterpenes, triterpenes, and triterpene derivatives (e.g., saponins) [22]. The anti-HIV activity of several terpenes has been evaluated in different cell lines, which has led to the identification of metabolites with antiviral effects, thereby demonstrating their potential pharmacological use in the prevention of this infection. They have been isolated from numerous plant species, such as Cipadessa cinerascens, Trigonostemon sp., Anisomeles indica, and Gardenia carinata, as well as from fungal species, such as Ganoderma lucidum (Table 1).

Monoterpenes and ciparasins B and P (Figure 2(a)), isolated from the cactus $C$. cinerascens, have shown significant anti-HIV activity; a cytotoxicity test using the 3(4,5-dimethylthiazol-2-yl)-2,5-diphenyltetrazolium bromide (MTT) assay showed that the anti-HIV activity of these metabolites is attributed to the inhibition of the cytopathic effect generated by HIV-1 NL4-3 on MT-4 cells, which have lymphoblast features and are highly susceptible to this viral infection [23].

Regarding diterpenes exhibiting anti-HIV activity, ovatodiolide (Figure 2(b)), isolated from the plant $A$. indica, inhibits $80 \%-90 \%$ of the cytopathic effect of HIV-1 [24].

Conversely, Huang et al. isolated a diterpene from the stems of the plant Excoecaria acerifolia Didr., which is designated as excocarinol A (Figure 2(c)) [25]. Subsequently, using the same plant, they reported four tigliane- and daphnane-type diterpenes called excoecafolins A (Figure 2(d)), B, and C and daphnopsis factor R2, respectively. The anti-HIV activities of these compounds were evaluated by determining the inhibition of the cytopathic effect caused by the virus, measured by syncytium formation and moderate cytotoxicity quantified with the MTT assay on the C8166 cell line [26].

The activity of plants belonging to Trigonostemon sp. has been studied. Li et al. evaluated the cytopathic effect of the virus in the presence of four daphnane-type derivatives of Trigonostemon lii. Two of these were synthesized de novo and named trigolins $\mathrm{C}$ and $\mathrm{G}$; the remaining two compounds evaluated have previously been reported as trigochinins $\mathrm{A}$ and F. Consequently, these compounds inhibited syncytium formation in the C8166 cell line [27]. Similarly, Cheng et al. isolated four new daphnane-type diterpenoids of Trigonostemon thyrsoideum called trigothysoids J (Figure 2(e)), $\mathrm{L}, \mathrm{N}$, and $\mathrm{O}$ with moderate anti-HIV activity and evaluated four other compounds previously reported as rediocides A, $\mathrm{C}$, and $\mathrm{F}$ and trigonosin $\mathrm{F}$, which displayed potent antiviral activity (half-maximal effective concentration $\left(\mathrm{EC}_{50}\right)$ from 0.001 to $0.015 \mathrm{nM}$ ) [28].

Regarding triterpenes of plants with anti-HIV activity, research was mainly focused on compounds derived from betulinic acid (Figure 2(f)), ursolic acid, and oleanolic acid.

Betulinic acids are pentacyclic triterpenes of natural origin, mainly found in the external bark of various plants that are often used in the timber industry. Particularly, they have been extracted from the methanolic extracts of Quisqualis fructus, dichloromethane extracts of Coussarea paniculata twigs, and ethanolic extracts of Anemone raddeana roots as well as from Vitex negundo, Doliocarpus schottianus leaves and wood, and Syzygium claviflorum leaves, among others [99]. These acids proved to have a wide variety of 


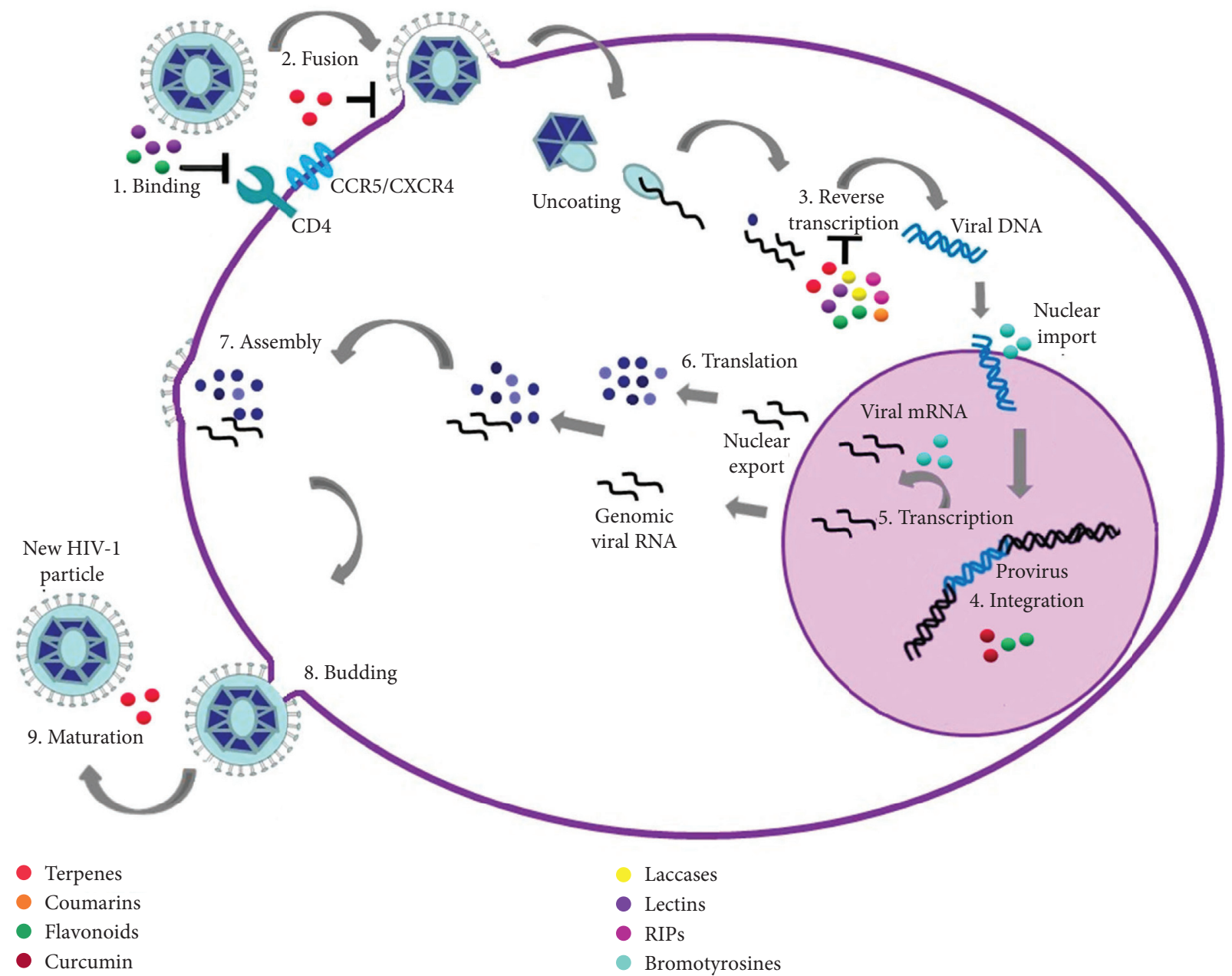

FIGURE 1: HIV-1 replication cycle exhibiting the sites of action of different natural products with anti-HIV-1 activity. Evidence suggests that flavonoids and lectins have an inhibitory effect on viral binding (1); terpenes inhibit virus fusion (2), whereas laccases, ribosome-inactivating proteins (RIPs), lectins, flavonoids, coumarins, and terpenes act on reverse transcriptase (3). Conversely, flavonoids and curcumin inhibit viral DNA integration (4), and bromotyrosines act on the transcription of the viral DNA (5). Finally, it has been reported that several terpenes act as inhibiting protease-mediated maturation of viral particles (9).

biological activities, such as antibacterial, antimalarial, antiinflammatory, antioxidative, anticarcinogenic, and anti-HIV effects. Their anti-HIV activity includes the inhibition of the entry to the target cell and inhibition of viral protease and RT; therefore, they may be used in combination with conventional antiretroviral therapy [99].

Fujioka et al. isolated the betulinic, platanic, and dihydrobetulinic acid components from S. claviflorum leaves, which exhibited anti-HIV activity by inhibiting the replication of the HIV-1 IIIB in $\mathrm{H} 9$ cells, as measured by detecting p24 antigen using enzyme-linked immunosorbent assay (ELISA), without significantly altering cell growth; this indicated that these compounds have a direct effect on viral replication and that the anti-HIV activity not caused by generalized cell cytotoxicity [29].

Other authors modified betulinic acid by introducing the 3,3-dimethylsuccinyl group replacing the acid C3 hydroxyl, generating 3-O-( $3^{\prime}, 3^{\prime}$-dimethylsuccinyl) betulinic acid (bevirimat), resulting in a considerable increase of its antiHIV activity. Kanamoto et al. evidenced the ability of this compound to inhibit HIV-1IIIB-induced cytopathic effect by MTT assay, further corroborated its anti-HIV activity by inhibition of p24 antigen expression in peripheral blood mononuclear cells (PBMCs) [30]. In conjunction, to determine the viral cycle step affecting bevirimat, they performed syncytium formation inhibition assays with Molt-4 cells, infectious virus release by multinuclear activation of galactosidase indicator (MAGI) assay with MAGI-CCR5 cells, electron microscopic observation, and the time-ofaddition assay [30]. The compound did not inhibit the formation of syncytia but inhibited the release of virus from infected cells; likewise, p24 antigen expression was different when it was associated to the cell where a variation of the enzyme concentration was observed according to the time of compound addition, while low levels were observed in the supernatant of treated cells. Therefore, these findings suggest that bevirimat interferes with HIV-1 assembly or exit [30]. In a subsequent study on this compound using MT-2 cells and PBMCs infected with HIV-1 NL4-3, a decrease in the p24 antigen levels was observed, indicating the inhibition of viral 
TABLe 1: Natural compounds with anti-HIV-1 activity extracted from fungi, plants, or marine sponges.

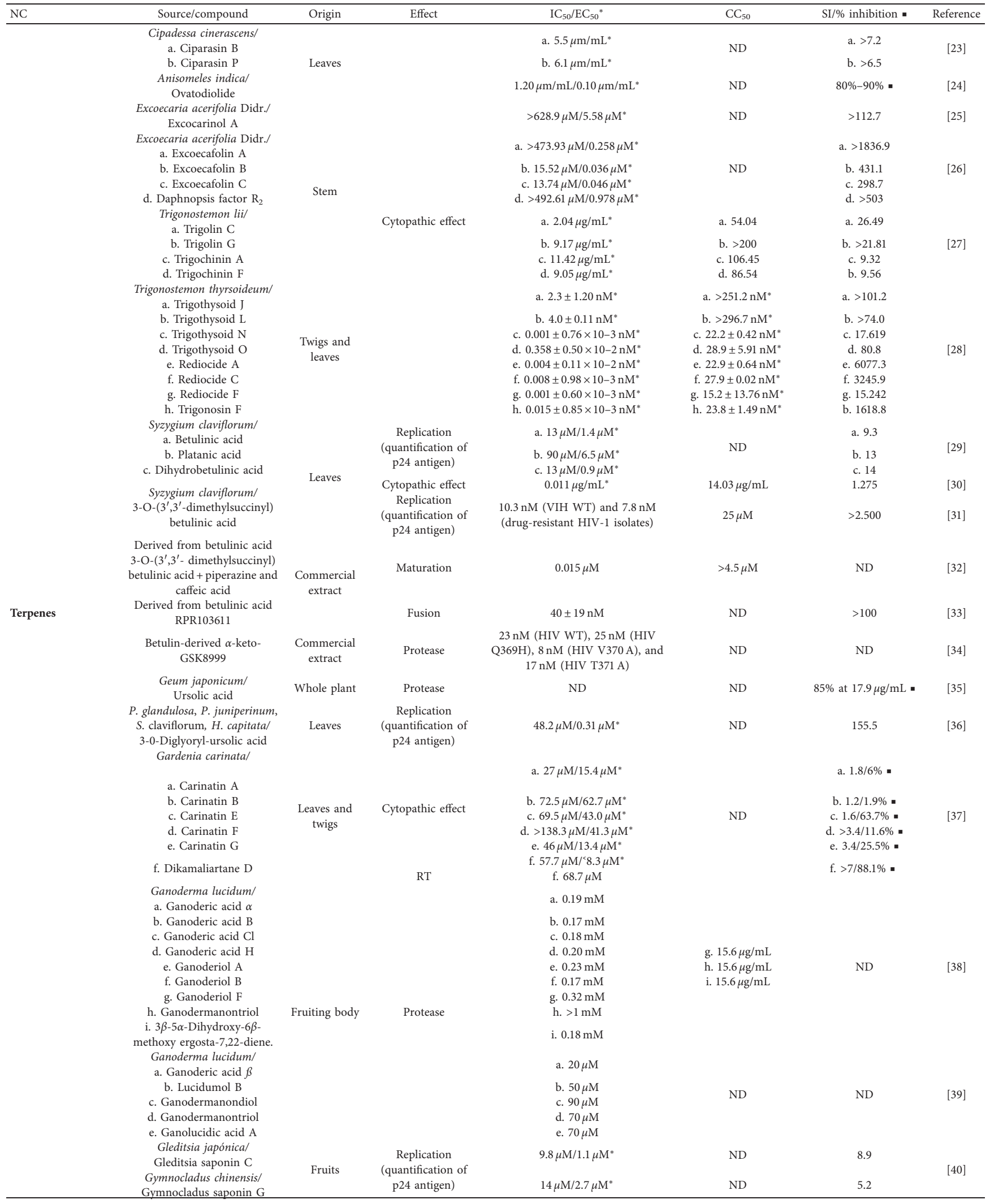


TABle 1: Continued.

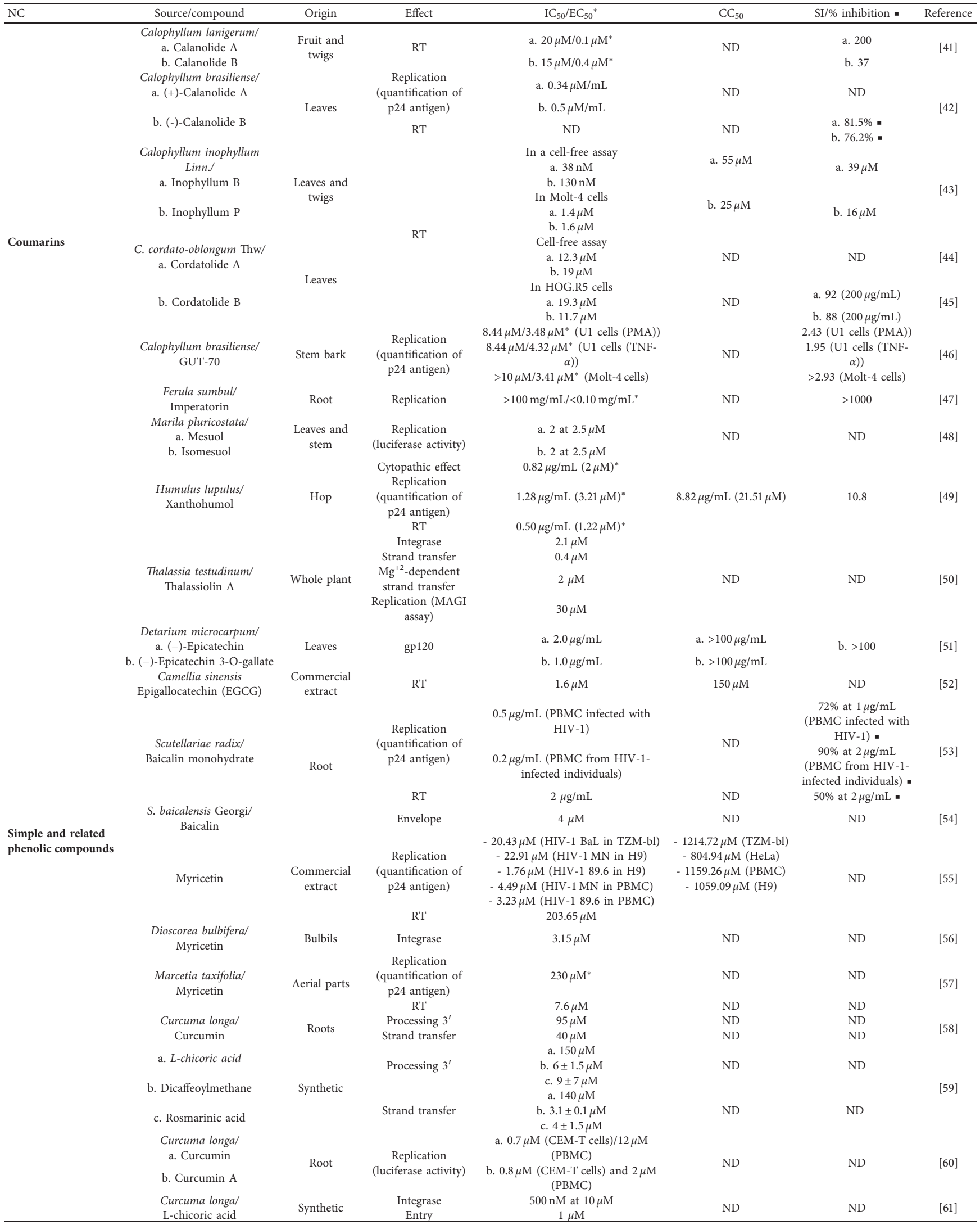


TABle 1: Continued.

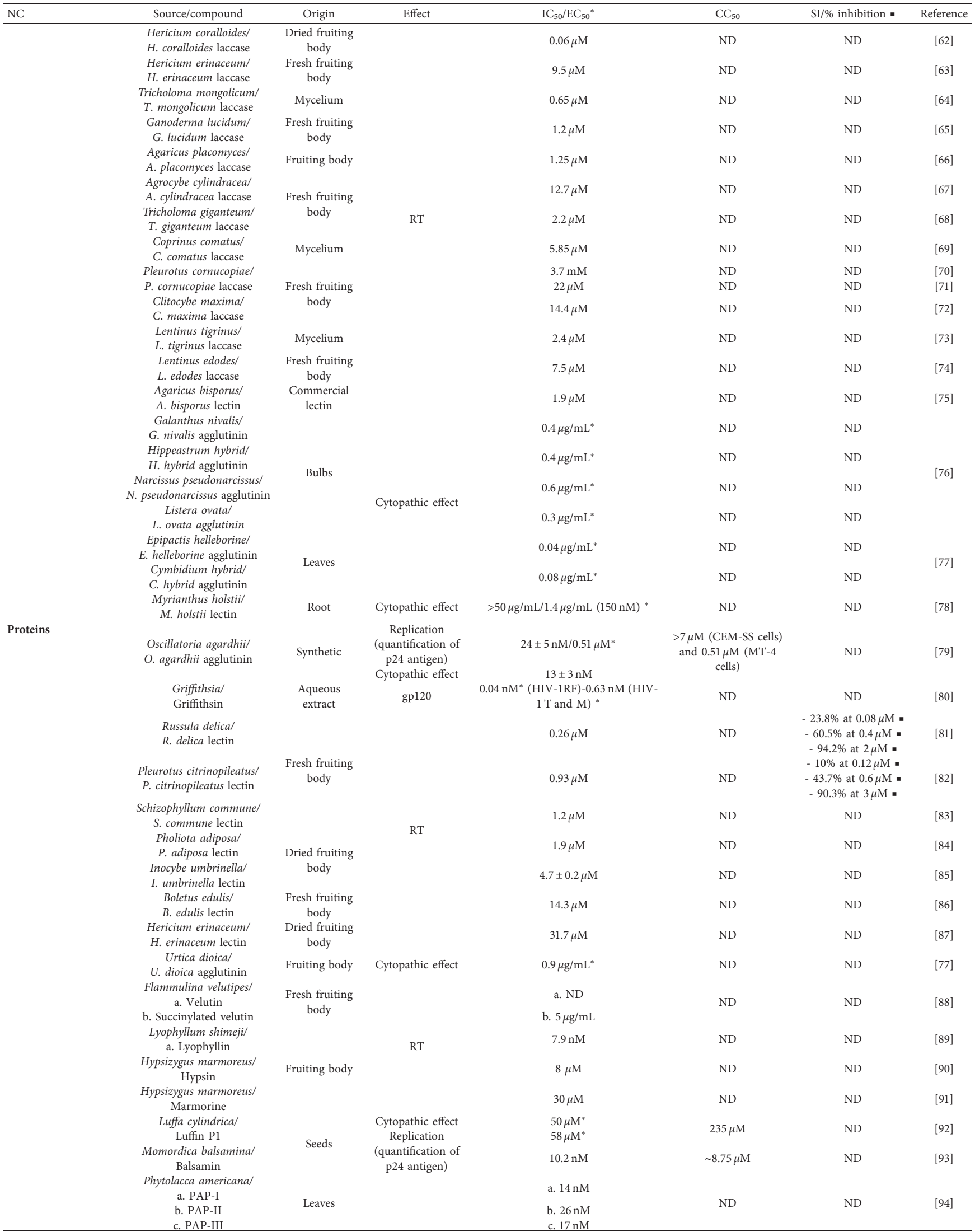


TABLE 1: Continued.

\begin{tabular}{|c|c|c|c|c|c|c|c|}
\hline $\mathrm{NC}$ & Source/compound & Origin & Effect & $\mathrm{IC}_{50} / \mathrm{EC}_{50}{ }^{*}$ & $\mathrm{CC}_{50}$ & SI/\% inhibition - & Reference \\
\hline \multirow{9}{*}{ Bromotyrosines } & Psammaplysine D & \multirow{9}{*}{$\begin{array}{l}\text { Marine } \\
\text { sponge }\end{array}$} & Replication & ND & ND & $51 \%$ at $0.1 \mu \mathrm{g} / \mathrm{mL}$. & [95] \\
\hline & & & $\begin{array}{l}\text { Replication (reverse } \\
\text { transcription assay) }\end{array}$ & $3.76 \mu \mathrm{M} / 2.5 \mu \mathrm{M}^{*}$ & ND & ND & [96] \\
\hline & Aeroplysinin-1 & & $\begin{array}{c}\text { Replication (MAGI } \\
\text { assay) }\end{array}$ & ND & ND & $74 \%$ at $20 \mu \mathrm{M}$ - & \multirow{3}{*}{ [97] } \\
\hline & & & Late transcripts & ND & ND & $48 \%$ at $10 \mu \mathrm{M}$. & \\
\hline & & & Nuclear import & ND & ND & $67 \%$ at $10 \mu \mathrm{M}$ - & \\
\hline & $\begin{array}{c}\text { Aiolochroia crassal } \\
\text { Fistularine } 3\end{array}$ & & $\begin{array}{l}\text { Replication (reverse } \\
\text { transcription assay) }\end{array}$ & $10.3 \mu \mathrm{M} / 6.9 \mu \mathrm{M}^{*}$ & ND & ND & {$[96]$} \\
\hline & Verongula rigida/ & & $\begin{array}{c}\text { Replication (MAGI } \\
\text { assay) }\end{array}$ & ND & ND & $57 \%$ at $80 \mu \mathrm{M}$ - & \multirow[t]{2}{*}{ [97] } \\
\hline & & & Early transcripts & ND & ND & $58 \%$ at $20 \mu \mathrm{M}$ - & \\
\hline & $\begin{array}{l}\text { Psammaplysilla purpurea/ } \\
\text { Mololipids mixture }\end{array}$ & & $\begin{array}{l}\text { Replication (SAR } \\
\text { study) }\end{array}$ & $>100 \mu \mathrm{M} / 52.2 \mathrm{mM}^{*}$ & ND & ND & [98] \\
\hline
\end{tabular}

NC: natural compound; $\mathbf{E C}_{\mathbf{5 0}}{ }^{*}$ : effective concentration $50 \%$; $\mathbf{I C}_{\mathbf{5 0}}$ : inhibitory concentration $50 \%$; $\mathbf{C C}_{\mathbf{5 0}}$ : cytotoxic concentration $50 \%$; $\mathbf{S I}$ : selectivity index; $\mathbf{R T}$ : reverse transcriptase; ND: nondetermined; $\cdot$ : percentage inhibition.

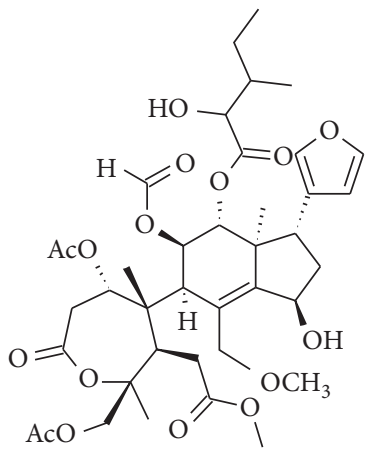

(a)

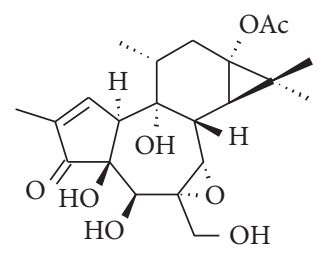

(d)<smiles>C=C1C(=O)O[C@@H](/C=C/C2C(=O)OC2CC/C=C(/C)CC)C1C</smiles><smiles>C=C[C@H]1C(O)CC2=C(CC[C@H]3[C@H](C)C(=O)CC[C@@]23C)[C@@H]1O</smiles>

(b)

(c)

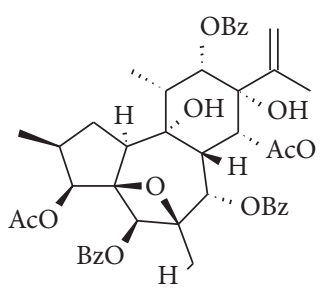

(e)

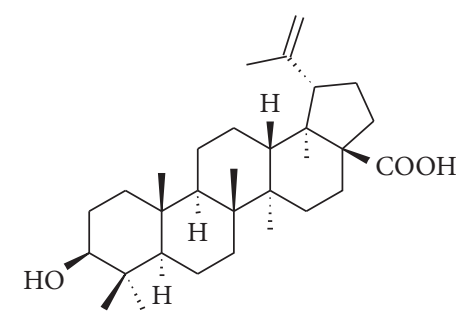

(f)

Figure 2: Chemical structure of representative terpenes with antiviral activity against HIV-1. (a) Ciparasin A. (b) Ovatodiolide. (c) Excocarinol A. (d) Excoecafolin A. (e) Trigothysoid J. (f) Betulinic acid.

replication [31]. Similarly, electronic microscopy using HeLa cells transfected with HIV demonstrated that modification of this compound is responsible for the inhibition of virus maturation, interfering with the standard processing of the polyprotein encoded by gag gene and leads to the production of defective capsids, resulting in a noninfectious virus [31].

The compound bevirimat was one of the first members of a candidate class of drugs against HIV and was tested in phase I $(n=32)$ [100], $n=42)$ [101] and II clinical trials $(n=24)$ [102]. Although global results of this clinical trial were positive, showing efficacy and safety [100, 101], the subsequent phases of the trial were not conducted owing to an ensuing description of a reduction in the efficacy of this drug in patients who were hosts of an HIV strain with mutations in a gag gene region, conferring a natural resistance to the drug [103]. Currently, trials with compounds derived from bevirimat are conducted, which undergo structure modifications to potentiate their antiviral activity [104]. Researchers, such as Zhao et al., have evaluated this compound by incorporating structures, such as caffeic acid and piperazine, which potentiated the activity against HIV-1 NL4-3 and bevirimat-resistant HIV strains (such as V370A), thereby inhibiting viral replication in MT-4 cells, as assessed by measuring p24 antigen levels with ELISA and virus maturation in TZM-bl cells [32].

In a structure-activity relationship (SAR) study, the triterpene RPR103611, derived from betulinic acid, was found to interfere with the fusion of HIV-1 with the cell for subsequent entry [33]. Furthermore, it was proposed that its antiviral activity depended on the stability of the envelope complex gp120/gp41, considering that this compound stops the fusion of CD4+ T cells with infected cells expressing 
these proteins, indicating the effect on virus entry [105]. However, its therapeutic value is limited owing to the lack of activity on R5 HIV-1 strains exhibited by RPR103611 [106].

Other researchers, such as Tang et al., have identified a new class of betulin-derived $\alpha$-keto-amides, which inhibited HIV-1 maturation in PBMCs. The compound that exhibited anti-HIV-1 activity was GSK8999; it exhibited the activity via the inhibition of gag proteolysis for the separation of the capsid-spacer peptide 1 , which is an essential step in virion maturation. This compound was evaluated against a panel of 62 HIV-1 strains and displayed effectiveness against 57 of them. Particularly, activity was observed against a virus with gag polymorphism in positions Q369H, V370A, and T371A, which produces resistance to maturation inhibitors, as well as against a wild strain [34]. These results reveal the therapeutic potential of this compound.

Furthermore, it was determined that ursolic acid, isolated from the methanolic extract from the whole plant of Geum japonicum, inhibits the activity of the viral protease. To this end, a synthetic peptide containing the cleavage site for p24-p17 was used as the gag precursor, and this cleavage product was quantified using HPLC [35]. Additionally, Kashiwada et al. isolated this compound from the plants Prunus glandulosa, Phoradendron juniperinum, S. claviflorum, and Hyptis capitata, and they modified it to generate 3-O-diglyoryl-ursolic acid, which inhibited viral replication in $\mathrm{H} 9$ cells [36].

Similarly, triterpenes called carinatins A, B, E, F, and G and dikamaliartane $\mathrm{D}$-derivatives from G. carinata-displayed anti-HIV activity by reducing syncytium formation in $1 \mathrm{~A} 2$ cell lines infected with the $\Delta$ Tat/ revMC99 virus, as evaluated by the MTT assay. Additionally, an assessment of the RT activity revealed an effect on this enzyme, particularly by dikamaliartane $\mathrm{D}$ [37].

Some triterpenes with anti-HIV activity have been fungal isolates, such as G. lucidum. Triterpenic compounds isolated from the fruiting body of this fungus include ganoderic acid $\mathrm{H}$, ganoderiol $\mathrm{A}$ and $\mathrm{B}$, ganoderic acid $\mathrm{Cl}$, ganoderic acid $\mathrm{B}$, and ganolucidic acid A, which were assessed using the MT-4 cell line by observing the inhibition of viral replication and moderate activity against the HIV-1 protease. Similarly, the compounds ganoderiol $\mathrm{F}$ and ganodermanontriol inhibited the cytopathic effect caused by the virus at a concentration quite lower than that of the previous compounds [38]. Using a cell-free assay, Min et al. evaluated the anti-HIV activity of some of these compounds, quantifying the fragments obtained from the cleavage of a peptide on which the viral protease specifically acted in the presence of these compounds, as assessed by HPLC via the determination of the significant inhibitory activity against the HIV-1 protease [39].

Saponins include the compounds gleditsia saponin C and gymnocladus saponin $\mathrm{G}$, isolated from the fruit of plants Gleditsia japonica and Gymnocladus chinensis, respectively. They exhibited inhibitory effects against the replication of the HIV-1 IIIB strain in H9 cells, as determined by measuring the p24 antigen levels using ELISA [40].

Therefore, terpenes are important owing to their potential as intermediaries in the synthesis of compounds with anti-HIV activity.

\section{Coumarins}

Coumarins are a wide group of phenolic compounds mainly found in the fruits and flowers of plants and play a role in plant growth, respiration and photosynthesis control, and defense against infections [107].

Coumarins have different biological properties in different cell systems. They have been known to exhibit antiinflammatory, antioxidative, antiallergic, and anticarcinogenic activities, as well as hepatoprotective effects [107]. Additionally, coumarins and their related compounds structurally isolated from the plants Calophyllum sp., Ferula sumbul, and Marila pluricostata have inhibited HIV replication, thereby presenting strong therapeutic potential (Table 1).

Coumarin calanolides A and $\mathrm{B}$, isolated from different species of the rainforest tree Calophyllum sp., are a new group of non-nucleoside RT inhibitors (NNRTIs). These compounds were initially isolated from Calophyllum lanigerum and evaluated in the CEM-SS cells, and they showed anti-HIV-1 activity via the inhibition of HIV-1 replication [41]. Subsequently, Huerta et al. isolated the compounds $(+)$-calanolide A (Figure 3(a)) and (-)-calanolide B (Figure 3(b)) from the leaves of C. brasiliense. Evaluation of their antiviral activity in MT-2 cells showed that they inhibited the replication of the HIV-1 IIIB strain and RT [42], but due to the low availability of the natural source from which this compound is isolated by the destruction of the natural habitat, the complete synthesis of calanolide $\mathrm{A}$ and $\mathrm{B}$ became necessary to continue with the pharmacological investigations as a possible antiviral [108-110].

Other researchers have evaluated the activity of the enantiomers of these compounds, observing in vitro activity only in unmodified (+)-calanolide A and (-)-calanolide B (costatolide) with an $\mathrm{EC}_{50}$ value of 0.2 and $0.3 \mu \mathrm{M}$, respectively [111]. Their effects are attributed to the interaction of these compounds with RT, altering its structural conformation and catalytic complex [111-113]. In particular, (+)-calanolide A has widely been studied owing to its inhibitory activity against zidovudine-resistant HIV-1 strains [41] and its synergic activity in combination with nucleoside analog RT inhibitors and NNRTIs [112].

Additionally, (+)-calanolide A produces cytotoxicity at concentrations 100-200 times higher than the $\mathrm{IC}_{50}$ in CEMSS cells, U937 cells, AA5 cells, PBMCs, and macrophages [113]. Similarly, it has been demonstrated that it produces no toxicity in the hepatic or splenic tissue of mice treated with high doses of this compound [114]. Based on available evidence, phase I clinical trials were initiated on (+)-calanolide $\mathrm{A}$ in which the evaluation of its effect in healthy controls showed a favorable pharmacokinetic profile when applying a single dose $(n=47)$ [115] or multiple doses $(n=39)$ in growing concentrations of this compound [116], displaying minimum toxicity, wherein the most common adverse effects were headaches, dizziness, and nausea $[115,116]$. These findings suggest that as a novel drug, this compound has high therapeutic activity.

Patil et al. evaluated the antiviral activity of inophyllums $\mathrm{B}$ and $\mathrm{P}$, a type of coumarin isolated from the tree 
<smiles>CCCc1cc(=O)oc2c3c(c4c(c12)OC(C)(C)C=C4)OC(C)C(C)C3O</smiles>

(a)<smiles>C/C=C(\C)C(=O)c1c(OC)c2c(c3c(CCC)cc(=O)oc13)OC(C)(C)C=C2</smiles>

(d)<smiles>CCCc1cc(=O)oc2c3c(c4c(c12)OC(C)(C)C=C4)O[C@H](C)[C@H](C)[C@H]3O</smiles>

(b)

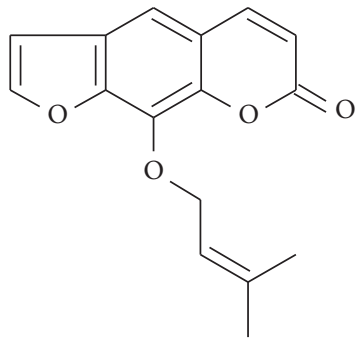

(e)<smiles>Cc1cc(=O)oc2c3c(c4c(c12)OC(C)(C)C=C4)O[C@@H](C)C[C@@H]3O</smiles>

(c)<smiles>CC(C)=CCc1c(O)c(C(=O)C(C)C)c(O)c2c(-c3ccccc3)cc(=O)oc12</smiles>

(f)

Figure 3: Chemical structure of representative coumarins with antiviral activity against HIV-1. (a) (+)-Calanolide A. (b) (-)-Calanolide B. (c) Cordatolide A. (d) GUT-70. (e) Imperatorin. (f) Mesuol.

C. inophyllum Linn., by conducting a scintillation proximity assay, which determines the activity of polymerase-type enzymes; it was found that these compounds inhibited HIV1 RT. Furthermore, they were active in the culture of Molt- 4 cells infected with HIV-1, and a weak cytotoxic effect was observed, as quantified using 2,3-bis-(2-methoxy-4-nitro-5sulfophenyl)-2H-tetrazolium-5-carboxanilide inner salt (XTT) assay [43].

Cordatolides are another example of an RT inhibitor, which are a type of pyranocoumarin derived from the plant C. cordato-oblongum Thw. Dharnaratne et al. found that cordatolide A (Figure 3(c)) and B inhibited RT activity, as assessed in cell-free assays [44] and human osteosarcoma cell systems expressing green fluorescent protein [45].

Another evaluated coumarin is GUT-70 (Figure 3(d)). This compound is a natural product derived from the stem bark of C. brasiliense. It has antiproliferative and proapoptotic activities for leukemia and lymphoma [46, 117]. Kudo et al. concluded that GUT-70 inhibits HIV-1 replication in acutely and chronically infected cells. Initially, by measuring the intracellular p24 antigen expression using flow cytometry, GUT-70 was determined to have a dose-dependent capacity to suppress viral replication in U1 cells stimulated with PMA or TNF- $\alpha$ as well as to inhibit HIV-1 NL4-3 replication in Molt-4 cells. Subsequently, real-time PCR analysis demonstrated that this compound inhibited HIV-1 Tat-Rev transcription $(p<0.05)$. Furthermore, these investigators analyzed the cytosolic and nuclear NF- $\kappa$ B expression by western blot in $\mathrm{U} 1$ cells in the presence or absence of the tested compound and observed that GUT-70 suppressed NF- $\kappa$ B p65 nuclear translocation but not its cytosolic degradation. Additionally, they conducted an electrophoretic mobility shift assay showing suppression of NF- $\kappa \mathrm{B}$ binding. Therefore, they concluded that HIV-1 replication was inhibited owing to the suppression of NF- $\kappa \mathrm{B}[46]$. NF$\kappa \mathrm{B}$ is a transcription factor involved in several biological processes, including immunity, inflammation, cancer, and viral infection. Specifically, the NF- $\kappa$ B pathway plays a key role in HIV-1 replication and reactivation of HIV-1 latency [118]. In 2014, Matsuda et al. used GUT-70 to evaluate cell membrane fluidity, an important factor for virus entry, and found a decrease in fluidity using fluorescent depolarization immunoassay in Molt-4 and PM1-CCR5 cell lines. Thereafter, using a fusion model system, it was observed that fused cells decreased in a dose-dependent manner with GUT-70 treatment, concluding that the compound inhibited cell-cell fusion. Subsequently, they found that intracellular expression and p24 antigen production, measured using ELISA, were reduced with GUT-70 treatment in a dose-dependent manner [117]. Recent advances in the development of drugs that inhibit NF- $\kappa$ B activation and their potential applications in inflammatory, autoimmune diseases and cancer are being considered [119, 120]. Although GUT-70 does not act directly against $\mathrm{HIV}-1$, its dual action in inhibiting HIV-1 entry and suppressing NF- $\kappa \mathrm{B}$ may be a promising therapeutic strategy against HIV-1.

Imperatorin (Figure 3(e)) is a furanocoumarin isolated from the plant F. sumbul. Zhou et al. found that this compound inhibits $\mathrm{HIV}-1$ replication in $\mathrm{H} 9$ cells and the growth of uninfected H9 cells [47]. Furthermore, in 2004, Sancho et al. isolated this compound from Opopanax chironium and assessed its activity in MT-2 cells infected with 
pNL4-3-Luc HIV-1 pseudotyped with VSV envelope; they observed a dose-dependent inhibition of the luciferase activity. Moreover, they analyzed the effects in terms of cellular toxicity by employing propidium iodide in HeLa cells, Jurkat cells, MT-2 cells, and PBMCs and observed a cytotoxic effect at concentrations 4-5 times higher than the $\mathrm{IC}_{50}$. The mechanism of action of this compound is based on the inhibition of the transcriptional activity of the HIV-1 long terminal repeat (LTR) promoter via a signaling pathway, implying the activation of the $\mathrm{Sp} 1$ transcription factor, which interacts with Tat to regulate the activity of this promoter. Imperatorin inhibits Sp1 and inhibits cyclin D1 expression, which stops the cell cycle at phase G1 (phase regulated by $S p 1$ ) [121]. On the other hand, in addition to the antiviral activity reported for this compound, it has been described as anti-inflammatory, anticancer, neuroprotective, antihypertensive, and antibacterial activity [122, 123].

Other types of coumarin, such as mesuol (Figure 3(f)) and isomesuol, were isolated from M. pluricostata. The antiviral activity of these compounds has been evaluated in Jurkat cells infected with HIV-1 pseudotyped with VSV envelope in which the suppression of HIV-1 replication was observed. Similarly, mesuol demonstrated strong anti-HIV activity in acutely infected PBMCs and inhibited the transcriptional activity of HIV-1 LTR induced by TNF- $\alpha$ by interfering with the $\mathrm{NF}-\kappa \mathrm{B}$ pathway. Additionally, this compound prevented the phosphorylation and transcriptional activity of subunit p65 of NF- $\kappa \mathrm{B}$ protein in cells stimulated with TNF- $\alpha$ [48].

\section{Simple and Related Phenolic Compounds}

4.1. Flavonoids. Flavonoids are polyphenols widely distributed in plants, which favor flower pigmentation and defense against microorganisms and arthropods. They are commonly found in fruits, vegetables, nuts, seeds, stems, and flowers and are typically included in the human diet in large amounts, thereby inhibiting parasitic growth caused by the interruption of some of their metabolic pathways and the decrease of adherence capacity to intestinal cells [124]. For centuries, preparations containing these compounds as the main active ingredients have been used to treat different human illnesses. In vitro studies have shown autoinflammatory, antioxidative, antimicrobial, anticarcinogenic, and antiallergic activities by flavonoids [125].

Flavonoids presenting activity against HIV-1 include derivatives from Humulus lupulus, Thalassia testudinum, and Carmela sinensis, among others (Table 1).

Some flavonoids, such as xanthohumol and thalassiolin A, exhibit anti-HIV activity owing to the inhibition of different key enzymes involved in viral replication $[49,50]$. Xanthohumol (Figure 4(a)), purified from the hops $H$. lupulus used in the production of beer, has shown antiHIV-1 activity. The anti-HIV-1 activity of this compound was evaluated in C8166 cells, where it demonstrated inhibition of the virus-induced cytopathic effect, inhibition of p24 antigen production, and RT activity, although without the inhibition of virus entry, at noncytotoxic concentrations. This compound further inhibited HIV-1 replication in HIV-

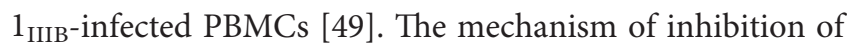
this compound was not completely explained in that study, and although it is proposed that the inhibition may occur during the process of reverse transcription, this remains unknown. However, the main mechanism of action for some types of cancer has been described to be based on the detention of growth and apoptosis of the implied cells via the $\mathrm{NF}-\kappa \mathrm{B}$ pathway [126]. Lastly, a toxicological study conducted on female Swiss nu/nu mice administered xanthohumol $\left(5 \times 10^{-4} \mathrm{M}\right)$ for 4 weeks showed safety when administered orally; no alteration of major organ functions was observed [127]. These results, added to the in vitro antiviral activity observed, indicate that this compound may represent a new therapeutic agent for HIV-1 infection.

Thalassiolin A is a natural flavone isolated from the Caribbean seagrass T. testudinum. The effects of this compound on HIV-1 integrase were assessed in the MT-2 cells in which inhibition of the viral cDNA end cutting and its strand transfer to $\mathrm{Mg}^{2+}$-dependent cellular DNA were observed. Similarly, thalassiolin A inhibited viral replication in the MAGI cell line and no resistant viral strains were observed, despite treatment for long periods. Additionally, no cytotoxicity was observed in MT-2 and HCT-116 cells [50].

In 1993, Mahmood et al. evaluated a series of flavonoids to determine their anti-HIV potential: (-)-epicatechin (Figure 4(b)) and (-)-epicatechin-3-O-gallate extracted from the plant Detarium microcarpum. These compounds were evaluated in the C8166 cell line, showing inhibition of gp120 production, as quantified using ELISA and a 50\% cytotoxic concentration, i.e., $\mathrm{CC}_{50}>100 \mu \mathrm{g} / \mathrm{mL}$ for both compounds observed in the MTT assay. Additionally, it was determined that (-)-epicatechin-3-O-gallate inhibited syncytium formation in $>90 \%$ of chronically infected H9 cells. This effect is achieved owing to the irreversible interaction of these flavonoids with gp120, thereby avoiding the fusion of the virus with the receptor CD4 [51]. Green tea (Camellia sinensis) contains various catechins and some isomers, such as epigallocatechin gallate (EGCG) (Figure 4(c)). It has been demonstrated that EGCG is one of the most powerful catechins, considering that it inhibits HIV-1 ineffectiveness by interfering in the fusion of gp120 with CD4 at physiological concentrations $(6 \mu \mathrm{mol} / \mathrm{L})$ [128-130]. Moreover, Yamaguchi et al. showed that EGCG is involved in the destruction of viral particles in cells acutely and chronically infected with HIV-1, exerting a dose-dependent effect [128]. Furthermore, in 2011, Li et al. reported the efficacy of this compound as an allosteric inhibitor of HIV-1 RT using HeLa-CD4-LTR- $\beta$-gal cells infected with HIV-1 [52]. In a phase I study in healthy volunteers, (-)-epicatechin was found to be well tolerated and to cause no adverse effects when administered orally at a single dose $(n=9)$ of 50,100 , or $200 \mathrm{mg}$ or multiple doses $(n=8)$ of $50 \mathrm{mg}$ daily [52]. These results suggest the involvement of flavonoids in the inhibition of different steps of the HIV replication cycle; they also represent a great potential for therapeutic use.

Baicalin (5,6,7-trihydroxyflavone-7-O- $\beta$-D-glucopyranosiduronic acid) (Figure $4(\mathrm{~d})$ ) is a flavonoid derived from the root of Scutellariae radix, which displayed the inhibition of HIV-1 replication in PBMCs of healthy and seropositive 
<smiles>COc1cc(O)c(CC=C(C)C)c(O)c1C(=O)/C=C/c1ccc(O)cc1</smiles>

(a)<smiles>O=C(O)C1O[C@@H](Oc2cc3oc(-c4ccccc4)cc(=O)c3c(O)c2O)[C@H](O)[C@H](O)[C@@H]1O</smiles>

(d)<smiles>Oc1cc(O)c2c(c1)O[C@H](c1ccc(O)c(O)c1)[C@H](O)C2</smiles>

(b)<smiles>O=C(O[C@H]1Cc2c(O)cc(O)cc2O[C@H]1c1cc(O)c(O)c(O)c1)c1cc(O)c(O)c(O)c1</smiles>

(c)<smiles>O=c1c(O)c(-c2cc(O)c(O)c(O)c2)oc2cc(O)cc(O)c12</smiles>

(e)<smiles>COc1cc(/C=C/C(=O)CC(=O)/C=C/c2ccc(O)c(OC)c2)ccc1O</smiles>

(f)

Figure 4: Chemical structure of representative simple and related phenolic compounds with antiviral activity against HIV-1. (a) Xanthohumol. (b) (-)-Epicatechin. (c) (-)-Epigallocatechin. (d) Baicalin. (e) Myricetin. (f) Curcumin.

controls for HIV-1. Antiviral activity was determined using the quantification of the p24 antigen levels with ELISA by observing inhibition of viral replication at dose-dependent concentrations of baicalin, with $72 \%$ reduction of the $\mathrm{p} 24$ antigen levels and an $\mathrm{IC}_{50}$ of $0.5 \mu \mathrm{g} / \mathrm{mL}$ in PBMCs of uninfected individuals, whereas an $\mathrm{IC}_{50}$ of $0.2 \mu \mathrm{g} / \mathrm{mL}$ was observed in infected individuals [53]. Additionally, at a concentration of $2 \mu \mathrm{g} / \mathrm{mL}$, this compound inhibited the activity of HIV-1 RT by $50 \%$ in an in vitro assay [53]. Similarly, Li et al. proved that baicalin isolated from Scutellaria baicalensis Georgi exhibits antiviral activity by inhibiting viral fusion mediated by the HIV-1 envelope proteins, for the $\mathrm{X} 4$ and $\mathrm{R} 5$ strains, in cells expressing CXCR4 or CCR5, thereby blocking virus entry [54].

Strong inhibitory activity against HIV-1 RT has been detected with myricetin (Figure 4(e)), which is derived from various plants, such as Dioscorea bulbifera and Marcetia taxifolia [55-57]. In 2014, Pasetto et al. conducted cytotoxicity tests by the resazurin fluorometric method using TZM-bl cells, HeLa cells, PBMCs, and H9 cells and found cellular viability of $\geq 85 \%$ when myricetin was used at a concentration of $100 \mu \mathrm{M}$. Additionally, the same cells were employed to evaluate anti-HIV-1 activity via quantification of the p24 antigen. These cells were infected with strains of $\mathrm{HIV}-1$, such as BaL (tropic R5), MN (tropic X4), and 89.6 (dual tropism X4R5); there was $87 \%$ inhibition of HIV-1 BaL in TZM-bl cells, $85 \%$ inhibition of HIV-1 MN, and $88 \%$ inhibition of HIV-1 89.6 in H9 cells. Similarly, in PBMCs, this compound inhibited HIV-1 MN and HIV-1 89.6 by $86 \%$ and $85 \%$, respectively. Finally, it was found that these effects are caused by the inhibition of viral RT [55]. Thereafter, using the multiple-well plate integration assay, Chaniad et al. determined that myricetin exhibited activity against HIV-1 integrase. Furthermore, using a molecular docking technique, it was observed that this compound was located extremely close to the integrase catalytic site and that it interacted with several amino acid residues involved in the $3^{\prime}$-processing and transfer reactions of the integrase strand [56]. Moreover, Ortega et al. assessed the antiviral effect of myricetin; they initially observed inhibition in HIV-1 replication when quantifying the p24 antigen levels using ELISA in MT-4 cells infected with HIV-1. Furthermore, they reported RT inhibition, which was measured with fluorescence assay [57].

These findings reveal the participation of flavonoids in the inhibition of different steps of the HIV-1 replication cycle, mainly the early stages, and demonstrate that they represent a group of substances with high potential for therapeutic use.

4.2. Curcumin. Curcumin (Figure 4(f)), a biologically active polyphenolic compound found in the yellow pigment of the plant C. longa, is widely used as a spice, food colorant, and preservative and exhibits anti-inflammatory, antioxidative, and anticarcinogenic activities [131]. This compound has exhibited activity against $\mathrm{HIV}-1$ via different mechanisms. First, its activity was assessed in PBMCs infected with

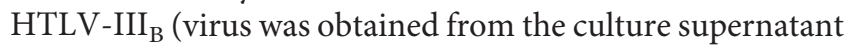
of chronically infected $\mathrm{H} 9$ cells) and treated with curcumin, wherein p24 antigen production was reduced in a dosedependent manner [132]. Thereafter, it was demonstrated that curcumin acts on HIV-1 integrase by interacting with its catalytic center, affecting $3^{\prime}$-processing and strand transfer, thus preventing the viral DNA insertion into the infected cell genome [58]. Furthermore, curcumin degrades Tat, as demonstrated by a transfected HEK-293T cell assay, wherein Tat levels were quantified in the presence of a protein synthesis inhibitor (cycloheximide) with or without curcumin and an increase in Tat degradation rate in the 
presence of curcumin was observed; however, a semiquantitative analysis using RT-PCR showed that Tat degradation occurred regardless of gene transcription. Additionally, curcumin decreased the Tat-mediated transactivation of the LTR promoter and inhibited the production of the virus, as observed in TZM-bl cells infected by HIV-1, thereby showing up to a $30 \%$ decrease in p24 antigen levels [133]. Other curcumin analogs, such as dicaffeoylmethane and rosmarinic acid, inhibit integrase activity in $3^{\prime}$-end processing and transfer of the viral DNA strand to cellular DNA, which was evidenced with the use of short oligonucleotides similar to the virus LTR [59].

Finally, in 2015, Kumari et al. synthesized curcumin A, a new curcumin-derived compound. They initially compared the inhibitory effects of curcumin and curcumin A on strains of HIV-1 luciferase (Luc) generated by a single round of infection in CEM-T cells and found similar $\mathrm{IC}_{50}$ values. Furthermore, in PBMCs, curcumin A showed a stronger inhibition of HIV-1 compared with curcumin. Furthermore, these compounds reduced the viability of CEM-T cells and PBMCs, which was quantified using calcein-AM and trypan blue, respectively. Using real-time PCR, they reported a reduction in the expression of gag and env mRNA encoded by this virus in cells treated with these compounds. Moreover, they quantified the early and late products of viral reverse transcription and found that curcumin and curcumin A showed similar inhibition of early transcription, whereas only curcumin A exhibited the inhibition of late transcription. Therefore, this modification renders curcumin A more efficient by inhibiting both stages of transcription, thus favoring its antiretroviral activity [60].

Curcumin has proven to be a safe compound when used in mice and humans, even when orally administered at high doses $(8000 \mathrm{mg} /$ day) to non-HIV population for 3 months [134]. However, it is not well absorbed when administered via this route. Therefore, a study was conducted combining curcumin with hepatic and intestinal metabolism inhibitors, and an increase in its bioavailability was observed [135].

Certain curcumin analogs, such as L-chicoric acid (LCA), showed an inhibitory effect on integrase and HIV-1 entry in MT-2 and H9 cell lines, respectively. A disintegration assay was conducted to determine this using a DNA probe connected to L-CA, and it was observed that integrase acts in an unspecific manner by cutting viral DNA. Using reaction kinetics assays, the noncovalent interaction between L-CA and viral integrase was determined. Therefore, it can be concluded that L-CA is a noncompetitive but reversible inhibitor of HIV-1 integrase [61].

\section{Proteins}

Among the great diversity of existing proteins, three main types of proteins exhibiting anti-HIV-1 activity have been identified: laccases, lectins, and RIPs.

5.1. Laccases. Laccases are a group of enzymes that belong to the polyphenol oxidase group and catalyze the reduction of oxygen to water via the oxidation of phenolic substrates
[136]. They are used in textile dyes, biosensors, and contaminated water detoxification, among other biotechnological processes, in addition to participation in lignin polymer formation in plants and lignin degradation as well as in pathogenic processes in fungi [69]. The latter are mainly included in the phylum Basidiomycota, which participates in wood decomposition [136].

Recently, certain fungal laccases have exhibited antiHIV-1 activity, among other properties, gaining the interest of the scientific community $[69,136,137]$. Researchers such as Wang and $\mathrm{Ng}$ have published a series of investigations, wherein they have isolated, purified, and physically and chemically characterized fungal laccases and have evaluated their capacity to inhibit HIV-1 infection via an action against virus RT in free-cell assays. These investigators observed anti-HIV activity in laccases isolated from the fruiting bodies or mycelia of different fungal species shown in Table 1, with an $\mathrm{IC}_{50}$ range of $0.06-22 \mu \mathrm{M}[62-74]$.

Laccases isolated from Hericium coralloides [62], Tricholoma mongolicum [64], G. lucidum [65], and Agaricus placomyces [66] exhibit the lowest $\mathrm{IC}_{50}$, allowing their use in the development of antiretroviral medications. However, it must be noted that the obtained $\mathrm{IC}_{50}$ values are not absolute indicators of a compound's potential and that SI must be considered to understand the potential effectiveness of the medication at the pharmacological level [67]. These researchers did not include a SI value in their publications, and their results are based on cell-free in vitro assays using which RT activity is measured; therefore, it is important to study anti-HIV activities of different laccases at the cellular level and to evaluate the inhibition of this enzyme and other viral proteins.

The molecular mechanisms involved in the inhibitory effect of laccases remain unclear. However, researchers Wang and $\mathrm{Ng}$ suggest that there is a protein-protein interaction between these enzymes and RT $[65,67,68]$, as observed by Böttcher and Grosse in 1997 [138]. Using immunoprecipitation/coprecipitation and western blot assays employing antibodies against these enzymes, these researchers concluded that completely processed RT inhibition may be owing to direct interaction with the protease of the same virus [138]. Some laccases, such as those extracted from the fungal species Cantharellus cibarius [139] and Albatrella dispansus [140], lack this ability. This is because these enzymes vary at the inter- and intraspecies levels and even in terms of the isoenzymes produced in different tissues in the same organism. This is justified by the presence of multiple genes in fungi that encode for the enzyme, and enzymes may vary in their percentage of glycosylation, generating interference in the interaction between the enzyme and viral proteins [136].

Zhao et al. reported that mycelia of the fungus Coprinus comatus contain an enzyme that is a strong suppressor of HepG2 (hepatocellular carcinoma) and MCF7 (human breast adenocarcinoma cell line) cell line proliferation and an inhibitor of HIV-1 RT, as assessed using ELISA, indicating that it is an antipathogenic protein [69]. Similarly, from the fungus Pleurotus cornucopiae, a new laccase with a molecular mass of $67 \mathrm{kDa}$ was isolated from fermentation 
broth via ionic exchange chromatography and gel filtration $[70,71]$. This laccase inhibits HIV-1 RT, and this activity was considerably inhibited by $\mathrm{Fe}^{3+}$ and $\mathrm{Hg}^{2+}$ and stimulated by $\mathrm{Cu}^{2+}$ and $\mathrm{Pb}^{2+}[70]$.

Laccase-producing basidiomycete fungi are distributed throughout the world. For example, in Colombia, to date, there are four genera of laccase-producing fungi attributed with anti-HIV activity reported in the local microflora, such as Clitocybe sp., Tricholoma sp. [141], Lentinus sp. [142], and Ganoderma sp. [143]. Within the vast unexplored flora inside and outside Colombia, there may be several other genera with therapeutic potential for HIV infection. Therefore, at the international and local levels, this wide group of laccases offers a global alternative for studying new compounds with anti-HIV activity with a potential for the development of antiretroviral therapies. Prior studies conducted by our research group show that laccases generate an inhibitory effect on HIV-1 replication and the viral reverse transcription process, which are evaluated in terms of early and late transcribed levels [144]. The maximum percentage inhibition of HIV replication was $86.4 \%$ and was obtained using an extract enriched with laccase derived from the fungus Lentinus sp., as measured with flow cytometry for green fluorescent protein (GFP) in U373-MAGI cells infected with a construct (pNL4-3 delta env) with a VSV envelope and marked with GFP. Additionally, the maximum percentage of inhibition of replication measured using ELISA for the p24 antigen was $68.1 \%$ and $60.1 \%$ for the extract enriched with laccase from Ganoderma sp. and Lentinus sp., respectively. Similarly, the percentages of maximum inhibition for the early transcripts were $86.6 \%$ for Ganoderma sp. and $91.3 \%$ for Lentinus sp. Finally, the percentages of maximum inhibition of late transcripts were 93.6\% for Ganoderma sp. and $90.5 \%$ for Lentinus sp. The laccase produced by these fungi appeared to be more efficient than those of other fungi in inhibiting the reverse transcription process [144]. These results provide the basis for future research, wherein the mechanism of action of the purified enzyme of these fungi, their biochemical properties, and other potential applications in pharmacology should be explored. To date, there are no reports on laccases from a nonfungal source with anti-HIV-1 activity.

5.2. Lectins. Lectins are di- or polyvalent carbohydratebinding proteins and are also known as hemagglutinins owing to their ability to agglutinate cells of the human immune system, regardless of whether they originate from a fungal or vegetable source [145]. Lectins are distributed in diverse living organisms, including animals, plants, bacteria, viruses, and fungi [146]; in the latter, they are involved in latency, growth, morphogenesis, and morphological changes following parasite infection as well as in molecular recognition during the early stages of fungal mycorrhization [147].

These proteins have garnered particular scientific interest because they display a series of exploitable biological activities, including antitumoral, antiproliferative, mitogenic, and immunopotentiation effects [84, 86, 148-151]. Additionally, the anti-HIV-1 activity demonstrated by lectins isolated from several fungal species is of special interest in the present study (Table 1) [75-87]. Although the mechanism of action by which these lectins inhibit RT activity remains unknown, researchers have suggested that it is owing to protein-protein interaction [84, 86, 87].

According to studies, lectins may be found in the fruiting bodies and mycelia of certain fungi. Similarly, it must be considered that the content of this compound varies based on age and fungal recollection time. Moreover, some fungal species have several lectins that may be closely related, differing in their isoelectric points; lectins isolated from the common mushroom Agaricus bisporus are an example [152]. These proteins may also vary in their molecular weight owing to their subunits' amino acid changes, as can be observed in lectins isolated from the mushroom P. cornucopiae [153]. Wang et al. mentioned that by 1998, 100 lectins were isolated from fungi, plants, and microorganisms [146]. A more detailed analysis of different lectin variants found in each of the specimens used to date may facilitate establishing a greater and comprehensive database of the types of lectins that inhibit HIV-1 RT. In particular, if tests are conducted to evidence other targets of virus inhibition besides RT, the number of compounds with therapeutic potential would significantly increase.

Other researchers have observed that a series of mannose-specific agglutinins (lectins) derived from the plants Galanthus nivalis, Hippeastrum hybrid, Narcissus pseudonarcissus, Listera ovata, Cymbidium hybrid, and Epipactis helleborine inhibit the cytopathic effect of HIV-1 on MT-4 cells $[76,77]$.

Other lectins present in plants, algae, and marine invertebrate animals exhibit anti-HIV activity [154]. Myrianthus holstii lectin, derived from the tree $M$. holstii, was assessed in CEM-SS cells; this lectin was found to be protective against the cytopathic effects of HIV-1 (syncytium formation) in nontoxic concentrations for the cell, suggesting that this lectin reversibly inhibits HIV-1 infection [78]. Oscillatoria agardhii agglutinins (OAAs) are generated by the green algae $O$. agardhii. Férir et al. reported that OAAs exhibited anti-HIV-1 activity in MT-4 cells; the researchers also used PBMCs and showed that OAAs inhibit $\mathrm{X} 4, \mathrm{R} 5$, and X4/R5 viral strains and inhibit several M-group HIV-1 subtypes. To prove that the effects mentioned were not the result of a cytotoxic effect on cells, the MTS/ phenazine ethosulfate method was implemented in PBMCs and MT-4 cells for evaluating cell viability. Similarly, they described that this lectin inhibited syncytium formation in infected and uninfected CD4+ T cells in a dose-dependent manner [79].

Swanson et al. reported that the BanLec lectin, isolated from Musa acuminate banana, exhibits anti-HIV-1 activity. Therefore, ELISA was performed, which showed that the activity of this compound is the result of direct binding to gp120, a protein found in the viral envelope, thereby preventing virus entry into the target cell [155].

Griffithsin (GRFT) is derived from red algae Griffithsia sp., which showed potent activity against several enveloped viruses. This compound inhibited the HIV replication in CEM-SS cells and PBMCs infected with HIV-1 isolates (R5 
and X4 strains) in which the RT activity and p24 antigen levels decreased and a blockade of cell-to-cell fusion and transmission of HIV-1 infection were observed [156]. This compound is one of the most powerful inhibitors of HIV entry because it inhibits viral replication at the plasma membrane level and specifically targets multiple mannoserich residues present in the gp120 of the viral envelope. Therefore, it is proposed to be a promising compound for the potential development of a new antiviral drug [157]. This compound inhibited HIV entry by targets multiple mannose-rich residues present in the gp120 of the viral envelope. Therefore, it is proposed to be a promising compound for the potential development of a new antiviral drug [157]. This compound also blocked infectivity against clades A, B, and C of the HIV [157-159]. Accordingly, studies have shown that GRFT is stable in a wide range of temperatures and $\mathrm{pH}$, stable in the cervicovaginal mucosa of macaque monkeys, demonstrating its potential as a topical microbicide [158].

In studies on human cell lines, Griffithsin showed high safety and efficacy profile because it has no mitogenic activity and does not induce the secretion of proinflammatory cytokines [160]. Subsequently, the effect of this compound was evaluated in two rodent species and minimal toxicity was found generating splenomegaly and hepatomegaly after application of single and repeated daily subcutaneous doses [161]. In addition, GRFT synergizes with the HIV-1 drugs tenofovir, maraviroc, and enfuvirtide, which could be used for microbicide development [162]. Kramzer et al. performed in vitro characterization of a preformulation of this compound and found physical, chemical, and biological stability profiles under stress conditions, except oxidative stress [163]. GRFT, being a lectin, is prone to oxidation; to overcome this property, an oxidation-resistant form of GRFT (Q-GRFT) has been developed and evaluated in rhesus macaque rectal tissue samples showing a nontoxic effect [164]. Also, new delivery strategies with different vehicles are being explored to improve its bioavailability $[165,166]$.

To date, two phase-I clinical studies have been initiated to investigate the potential toxicity of GRFT in healthy populations. The first study aims to evaluate the safety of GRFT in a vaginally applied gel in healthy women [167]. The second ongoing study is called PREVENT (pre-exposure prevention of viral entry), which evaluates the safety and pharmacokinetics of Q-GRFT enema administered rectally in adults practicing receptive anal intercourse [168].

Similarly, lectins found in Phaseolus vulgaris, Momordica charantia, and Ricinus communis inhibited HIV-1 RT and the $\mathrm{N}$-glycohydrolase enzymes ( $\alpha$-glucosidase and $\beta$-glucosidase) [75]. $\mathrm{N}$-glycohydrolase enzymes are commonly found in the Golgi apparatus of host cells and are responsible for protein glycosylation. Another study showed a decrease in the infectivity of HIV virions caused by the inhibition of these proteins, considering that viral glycoproteins are highly glycosylated [169].

It has been suggested that several lectins preserve their biological activity as they pass through the digestive tract [146]. This implies that the anti-HIV activity of lectins isolated from some fungi, such as A. bisporus and P. vulgaris, can maintain their antiviral effect in the digestive tract after consumption; therefore, they can be explored for possible benefits as a frequent component of the diet of patients with HIV or of uninfected individuals as a protective measure. This, in addition to the fact that some lectin-producing fungal genera, such as Boletus sp., are largely distributed worldwide and particularly in Colombia [141], renders research on lectins an area of interest for HIV researchers.

\subsection{Ribosome-Inactivating Proteins (RIPs). RIPs are com-} pounds that irreversibly inhibit ribosomes, which are found in eukaryotic cells. For the inhibitory action, RIP uses its RNA-N-glycosidase activity, which hydrolyses the N-glycosidic bond between the adenine and ribose of the nucleoside A-4324 of the $28 \mathrm{~S}$ subunit of rRNA. This released adenine can be found in a preserved location essential for ribosomal function in eukaryotes [170]. RIPs are reportedly present in several angiosperms, fungi, and bacteria [171]. They are involved in a series of activities, including the inhibition of translation and N-glycosidase as well as antimitogenic, immunomodulating, antiproliferative, antifungal, and antiviral activities [170]. The antiviral activity includes the inhibitory ability of HIV-1 RT.

The HIV-1 RT inhibitory activity in fungi has been described by Wang and $\mathrm{Ng}$, who reported RIPs as virus inhibitors (Table 1). Velutin, an RIP composed of a single chain with a molecular weight of $13.8 \mathrm{kDa}$, was isolated from winter mushroom Flammulina velutipes. This protein completely inhibited HIV-1 RT at a concentration of $5 \mathrm{mg} /$ $\mathrm{mL}$ [88]. Following succinylation, its activity showed an increase because this process led to changes, such as variation in the net load of the protein, which may significantly alter its possible interactions with other molecules, similar to that described for succinylation of ovalbumin [172].

Although other RIPs that act on HIV-1 RT, such as lyophyllin [89], hypsin [90], and marmorine [91], have been identified, little is known about their mechanism of action.

Numerous RIPs have been identified in several plant families, including trichosanthin (TCS) isolated from the Chinese medicinal herb Trichosanthes kirilowii, which has immunoregulatory, anticancer, and anti-HIV activities [173]. In 1989, McGrath et al. reported the antiviral activity exerted by this compound when inhibiting HIV-1 replication. This inhibition was observed in acutely infected T cells, which showed a decrease in cytopathic effects and p24 antigen levels. Furthermore, a decrease was reported in the p24 antigen levels of chronically infected macrophages [174]. Subsequently, Wang et al., after conducting an in vitro test using H9 cells, found that the anti-HIV activity of TCS was achieved via the apoptotic effect in infected cells. At a concentration of $24 \mu \mathrm{g} / \mathrm{mL}$, trichosanthin-induced apoptosis occurred in $8.4 \%$ of uninfected $\mathrm{H} 9$ cells and $24.5 \%$ of $\mathrm{H} 9$ cells chronically infected with HIV-1 [175]. Nevertheless, the antiviral mechanism remains controversial because several researchers have reported that this effect is owing to its activity in HIV-1 integration because HIV-infected 293T cells showed a dosage-dependent blocking in HIV-1 integration. Moreover, a glutathione S-transferase pull- 
<smiles>COC1=C(Br)C(C)=C(Br)C=CO[C@]12ON=C(C(=O)NCCCOc1c(Br)cc(C(O)CNC(C)=O)cc1Br)C2O</smiles>

(a)

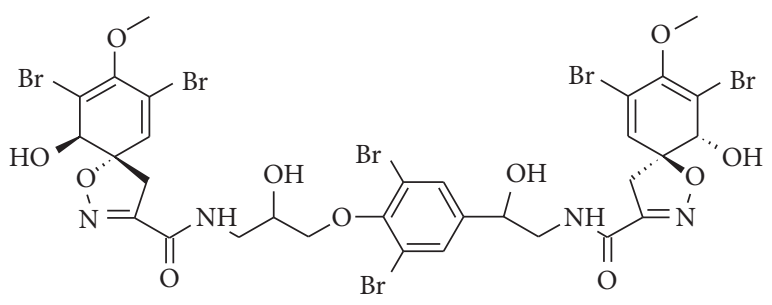

(c)<smiles>COC1=C(Br)[C@H](O)[C@H](O)C=C1Br</smiles>

(b)

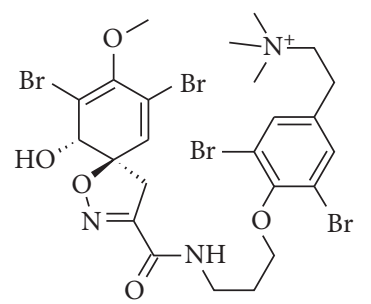

(d)

FIgURE 5: Chemical structure of bromotyrosines with antiviral activity against HIV-1. (a) Psammaplysine D. (b) Purealidin B. (c) Fisturalin3. (d) Aeroplysinina-1.

down assay was conducted to observe interactions between in vitro proteins, and it was possible to establish that TCS specifically inhibits HIV-1 integration by depurating HIV-1 LTR [176]. Other investigators have shown that TCS can penetrate the viral membrane via lipid rafts, wherein it is protected against protease digestion. Although this internalization does not directly destroy the virus, it can significantly reduce its replication [177].

Patients with AIDS have been included in several clinical trials conducted on TCS. During the first phase I/II clinical test, a decrease was observed in the p24 antigen levels and an increase was observed in the blood CD4+ T cell count [178]. Thereafter, this drug was tested in phase II clinical trials as an adjunct to zidovudine treatment, a classical medication of ART, which resulted in an increase in the CD4+ T cell count during the treatment period [179]. In the same year, Kahn et al. conducted a study including 22 patients with AIDS to evaluate the safety, pharmacokinetics, and immunological effects of multiple doses of this drug. The results showed an increase in the CD4+ and CD8+ T cell count of up to 28 days after the application of the compound [180]. Nonetheless, patients have experienced several side effects, which were probably associated with cytotoxic effects; therefore, it is important to consider different variables related to its use or its chemical structure to increase the antiviral potential of this compound in the future.

Luffin P1 is a small RIP exhibiting anti-HIV-1 activity that is isolated from the seeds of the plant sponge gourd Luffa cylindrica. This protein was evaluated in the C8166 cell line in which it inhibited syncytium formation and p24 antigen production. Luffin P1 was cytotoxic in uninfected cells; however, its effect on HIV replication was considerably stronger. In the present study, we demonstrated that luffin P1 interacts with Rev response elements (RRE) in a dosedependent manner, indicating that it could compete with Rev for RREs in infected cells, thereby decreasing the mRNA export rate of HIV-1 to the cytoplasm for protein synthesis and virion assembly [92].

Balsamin, which is isolated from the bitter melon Momordica balsamina, inhibits HIV-1 replication in T cell lines and primary human $\mathrm{CD} 4+\mathrm{T}$ cells. This antiviral compound has a high likelihood of exerting its activity on the viral translation of proteins before budding and viral release. Also, this RIP prevents the replication of the influenza virus [93].

Zarling et al. reported that the antiviral protein isolated from Phytolacca americana leaves, known as pokeweed antiviral protein (PAP), inhibits p24 antigen production, as measured using radioimmunoprecipitation in $\mathrm{HIV}$-infected primary $\mathrm{CD} 4+\mathrm{T}$ cells and macrophages, with an $\mathrm{IC}_{50}$ of $0.5 \mathrm{nM}[181]$. At a later stage, the same investigators showed that compared with nonconjugated PAP, PAP conjugated with monoclonal antibodies against CD4 (anti-CD4-PAP) showed more efficient inhibition of viral replication in CD4+ T cells infected with HIV-1 [182]. The PAP isomers (PAP-I, PAP-II, and PAP-III) exert anti-HIV-1 activities by inhibiting viral replication (quantified using ELISA with the p24 antigen) in PBMCs [94]. In 2015, Krivdova and Hudak reported that the mRNA of the Vif protein of HIV is the PAP substrate. Vif induces degradation of APOBEC3G, a potent inhibitor of the HIV reverse transcription process; therefore, PAP restores APOBEC3G levels, facilitating its proper functioning as a protective factor against viral infections [183].

\section{Bromotyrosines}

Bromotyrosines are a type of molecule whose chemical structure is based on L-tyrosine, showing replacements by bromide atoms at the third or the third and fifth positions, generating mono- or dihalogenated substances, respectively [184]. They can be found in several animal and plant tissues, 
being mainly isolated from marine sponges of the order Verongida [185] (Table 1). Currently, these compounds have thoroughly been studied owing to their cytotoxic, antiparasitic, anticancer, and antiviral activities [97]. Several bromotyrosine-derived compounds with anti-HIV-1 activity have been reported.

In 1993, Ichiba et al. reported that psammaplysine D (Figure 5(a)) exhibits anti-HIV activity by presenting 51\% inhibition at $0.1 \mathrm{pg} / \mathrm{mL}$ against the HIV-1 RF strain from Haiti [95]. Subsequently, using the RT assay, it was possible to determine that aeroplysinin-1 (Figure 5(b)) and fistularin3 (Figure 5(c)) isolated from the Caribbean sponge species Verongula rigida and Aiolochroia crassa, respectively, which are sponges of the order Verongida, inhibited HIV-1 LAI replication in PBMCs [96]. Results of our studies showed that these compounds, along with purealidin B (Figure 5(d)), exhibited anti-HIV-1 activity. To this end, the U373-MAGI cell line infected with a pseudotyped virus (HIV-GFP-VSV$\mathrm{G})$ in the presence or absence of these compounds and the percentage of cells infected were evaluated using flow cytometry for GFP, and dose-dependent inhibition of viral replication caused by aeroplysine-1 and purealidin B was observed. Similarly, three compounds inhibited reverse transcription and nuclear import of viral DNA as observed via real-time PCR quantification of the early and late transcripts of RT and the viral 2-LTR circle, respectively [97].

Mololipids are another derivative of bromotyrosines that exhibit anti-HIV-1 activity (assessed by conducting a SAR study), which proved to be noncytotoxic to PBMC, as assessed by the MTT assay [98].

\section{Conclusion}

Infections caused by HIV is one of the main public health issues worldwide attributed to the economic, political, and social barriers that limit access to antiretroviral drugs for a large part of the population as well as to the high resistance levels currently reported for the virus. Therefore, research in this area is ongoing even after more than four decades and is aimed at finding a safe treatment that not only inhibits the replication of the virus but also succeeds in restoring the destroyed immune system.

In the present review, we described numerous compounds of natural origin, such as from plants, fungi, and marine sponges, identified as strong inhibitors of various stages of the HIV-1 replication cycle, from entry to transcription, translation, and exit processes. Research on natural products and their derivatives with anti-HIV activity may lead to the development of strong antiretroviral drugs, with few side effects and easy accessibility to patients with HIV infection. This group of molecules includes terpenes, coumarins, flavonoids, laccases, lectins, RIPs, and bromotyrosines as well as their derivatives and agonists. Identification of compounds with the highest therapeutic potential for HIV infection is crucial for the development of future alternative and/or supplemental therapies to ART. Therefore, further research on such compounds is warranted to understand their mechanisms of action against HIV and to conduct clinical trials with the most promising compounds.

\section{Data Availability}

No data were used in this study.

\section{Conflicts of Interest}

No potential conflicts of interest were reported by the authors.

\section{Acknowledgments}

This work was supported by COLCIENCIAS (code 141577757439), Universidad Cooperativa de Colombia (code INV2407), and Universidad de Antioquia (UdeA).

\section{References}

[1] S. G. Deeks, S. R. Lewin, and D. V. Havlir, "The end of AIDS: HIV infection as a chronic disease," The Lancet, vol. 382, no. 9903, pp. 1525-1533, 2013.

[2] UNAIDS, Global HIV \& AIDS Statistics-2020 Fact Sheet, UNAIDS, Geneva, Switzerland, unaids.org2020, 2020.

[3] S. B. Laskey and R. F. Siliciano, "A mechanistic theory to explain the efficacy of antiretroviral therapy," Nature Reviews Microbiology, vol. 12, no. 11, pp. 772-780, 2014.

[4] T. B. Ng, B. Huang, W. P. Fong, and H. W. Yeung, "Antihuman immunodeficiency virus (anti-HIV) natural products with special emphasis on HIV reverse transcriptase inhibitors," Life Sciences, vol. 61, no. 10, pp. 933-949, 1997.

[5] Panel on Antiretroviral Guidelines for Adults and Adolescents, Guidelines for the Use of Antiretroviral Agents in Adults and Adolescents with HIV, Department of Health and $\mathrm{Hu}-$ man Services, Washington, DC, USA, 2019.

[6] Organization WH, Guideline on when to Start Antiretroviral Therapy and on Pre-exposure Prophylaxis for HIV, 78 pages, World Health Organization, Geneva, Switzerland, 2015.

[7] D. King, S. Tomkins, A. Waters et al., "Intracellular cytokines may model immunoregulation of abacavir hypersensitivity in HIV-infected subjects," Journal of Allergy and Clinical Immunology, vol. 115, no. 5, pp. 1081-1087, 2005.

[8] J. Stekler, J. Maenza, C. Stevens et al., "Abacavir hypersensitivity reaction in primary HIV infection," Aids, vol. 20, no. 9, pp. 1269-1274, 2006.

[9] B. S. Peters and K. Conway, "Therapy for HIV," Advances in Dental Research, vol. 23, no. 1, pp. 23-27, 2011.

[10] V. Montessori, N. Press, M. Harris, L. Akagi, and J. S. Montaner, "Adverse effects of antiretroviral therapy for HIV infection," CMAJ: Canadian Medical Association Journal, vol. 170, no. 2, pp. 229-238, 2004.

[11] S. Esser, D. Helbig, U. Hillen, J. Dissemond, and S. Grabbe, "Side effects of HIV therapy," JDDG, vol. 5, no. 9, pp. 745-754, 2007.

[12] L. Menéndez-Arias, "Targeting HIV: antiretroviral therapy and development of drug resistance," Trends in Pharmacological Sciences, vol. 23, no. 8, pp. 381-388, 2002.

[13] E. M. Gardner, W. J. Burman, J. F. Steiner, P. L. Anderson, and D. R. Bangsberg, "Antiretroviral medication adherence and the development of class-specific antiretroviral resistance," AIDS, vol. 23, no. 9, pp. 1035-1046, 2009.

[14] J. B. Nachega, V. C. Marconi, G. U. van Zyl et al., "HIV treatment adherence, drug resistance, virologic failure: evolving concepts," Infectious Disorders Drug Targets, vol. 11, no. 2, pp. 167-174, 2011. 
[15] P. Yeni, "Update on HAART in HIV," Journal of Hepatology, vol. 44, 2006.

[16] F. Nakagawa, A. Miners, C. J. Smith et al., "Projected lifetime healthcare costs associated with HIV infection," PLoS One, vol. 10, no. 4, Article ID e0125018, 2015.

[17] N. E. Thomford, D. A. Senthebane, A. Rowe et al., "Natural products for drug discovery in the 21st century: innovations for novel drug discovery," International Journal of Molecular Sciences, vol. 19, no. 6, 2018.

[18] L. Palmisano and S. Vella, "A brief history of antiretroviral therapy of HIV infection: success and challenges," Annali dell'Istituto Superiore di Sanita, vol. 47, no. 1, pp. 44-48, 2011.

[19] K. Vermani and S. Garg, "Herbal medicines for sexually transmitted diseases and AIDS," Journal of Ethnopharmacology, vol. 80, no. 1, pp. 49-66, 2002.

[20] D. Chattopadhyay, M. C. Sarkar, T. Chatterjee et al., "Recent advancements for the evaluation of anti-viral activities of natural products," New Biotechnology, vol. 25, no. 5, pp. 347-368, 2009.

[21] K. Yazaki, G.-i. Arimura, and T. Ohnishi, "Hidden' terpenoids in plants: their biosynthesis, localization and ecological roles," Plant and Cell Physiology, vol. 58, no. 10, pp. 1615-1621, 2017.

[22] D. Tholl, "Biosynthesis and biological functions of terpenoids in plants," Biotechnology of Isoprenoids, vol. 148, pp. 63-106, 2015.

[23] J.-H. Yu, G.-C. Wang, Y.-S. Han, Y. Wu, M. A. Wainberg, and J.-M. Yue, "Limonoids with anti-HIV activity from Cipadessa cinerascens," Journal of Natural Products, vol. 78, no. 6, pp. 1243-1252, 2015.

[24] M. Shahidul Alam, M. A. Quader, and M. A. Rashid, "HIVinhibitory diterpenoid from Anisomeles indica," Fitoterapia, vol. 71, no. 5, pp. 574-576, 2000.

[25] S.-Z. Huang, X. Zhang, Q.-Y. Ma et al., "Terpenoids and their anti-HIV-1 activities from Excoecaria acerifolia," Fitoterapia, vol. 91, pp. 224-230, 2013.

[26] S.-Z. Huang, X. Zhang, Q.-Y. Ma et al., "Anti-HIV-1 tigliane diterpenoids from Excoecaria acertiflia Didr," Fitoterapia, vol. 95, pp. 34-41, 2014.

[27] S.-F. Li, Y. Zhang, N. Huang et al., "Daphnane diterpenoids from the stems of Trigonostemon lii and their anti-HIV-1 activity," Phytochemistry, vol. 93, pp. 216-221, 2013.

[28] Y.-Y. Cheng, H. Chen, H.-P. He et al., "Anti-HIV active daphnane diterpenoids from Trigonostemon thyrsoideum," Phytochemistry, vol. 96, pp. 360-369, 2013.

[29] T. Fujioka, Y. Kashiwada, R. E. Kilkuskie et al., "Anti-AIDS agents, 11. Betulinic acid and platanic acid as anti-HIV principles from Syzigium claviflorum, and the anti-HIV activity of structurally related triterpenoids," Journal of Natural Products, vol. 57, no. 2, pp. 243-247, 1994.

[30] T. Kanamoto, Y. Kashiwada, K. Kanbara et al., "Anti-human immunodeficiency virus activity of YK-FH312 (a betulinic acid derivative), a novel compound blocking viral maturation," Antimicrobial Agents and Chemotherapy, vol. 45, no. 4, pp. 1225-1230, 2001.

[31] F. Li, R. Goila-Gaur, K. Salzwedel et al., "PA-457: a potent HIV inhibitor that disrupts core condensation by targeting a late step in Gag processing," Proceedings of the National Academy of Sciences, vol. 100, no. 23, pp. 13555-13560, 2003.

[32] Y. Zhao, Q. Gu, S. L. Morris-Natschke, C.-H. Chen, and K.-H. Lee, "Incorporation of privileged structures into bevirimat can improve activity against wild-type and bevirimat-resistant HIV-1," Journal of Medicinal Chemistry, vol. 59, no. 19, pp. 9262-9268, 2016.

[33] F. Soler, C. Poujade, M. Evers et al., "Betulinic acid derivatives: a new class of specific inhibitors of human immunodeficiency virus type 1 entry," Journal of Medicinal Chemistry, vol. 39, no. 5, pp. 1069-1083, 1996.

[34] J. Tang, S. A. Jones, J. L. Jeffrey et al., "Discovery of a novel and potent class of anti-HIV-1 maturation inhibitors with improved virology profile against gag polymorphisms," Bioorganic \& Medicinal Chemistry Letters, vol. 27, no. 12, pp. 2689-2694, 2017.

[35] H.-X. Xu, F.-Q. Zeng, M. Wan, and K.-Y. Sim, "Anti-HIV triterpene acids fromGeum japonicum," Journal of Natural Products, vol. 59, no. 7, pp. 643-645, 1996.

[36] Y. Kashiwada, T. Nagao, A. Hashimoto et al., "Anti-AIDS agents 38. Anti-HIV activity of 3-O-acyl ursolic acid Derivatives1," Journal of Natural Products, vol. 63, no. 12, pp. 1619-1622, 2000.

[37] N. Kongkum, P. Tuchinda, M. Pohmakotr et al., "Cytotoxic, antitopoisomerase II $\alpha$, and anti-HIV-1 activities of triterpenoids isolated from leaves and twigs of Gardenia carinata," Journal of Natural Products, vol. 76, no. 4, pp. 530-537, 2013.

[38] S. el-Mekkawy, M. R. Meselhy, N. Nakamura et al., "AntiHIV-1 and anti-HIV-1-protease substances from Ganoderma lucidum," Phytochemistry, vol. 49, no. 6, pp. 1651-1657, 1998.

[39] B.-S. Min, N. Nakamura, H. Miyashiro, K.-W. Bae, and M. Hattori, "Triterpenes from the spores of Ganoderma lucidum and their inhibitory activity against HIV-1 protease," Chemical and Pharmaceutical Bulletin, vol. 46, no. 10, pp. 1607-1612, 1998.

[40] T. Konoshima, I. Yasuda, Y. Kashiwada, L. M. Cosentino, and K.-H. Lee, "Anti-AIDS agents, 21. Triterpenoid saponins as anti-HIV principles from fruits of gleditsia japonica and gymnocladus chinesis, and a structure-activity correlation," Journal of Natural Products, vol. 58, no. 9, pp. 1372-1377, 1995.

[41] Y. Kashman, K. R. Gustafson, R. W. Fuller et al., "HIV inhibitory natural products. Part 7 . The calanolides, a novel HIV-inhibitory class of coumarin derivatives from the tropical rainforest tree, Calophyllum lanigerum," Journal of Medicinal Chemistry, vol. 35, no. 15, pp. 2735-2743, 1992.

[42] M. Huerta-Reyes, M. d. C. Basualdo, F. Abe, M. JimenezEstrada, C. Soler, and R. Reyes-Chilpa, "HIV-1 inhibitory compounds from Calophyllum brasiliense leaves," Biological and Pharmaceutical Bulletin, vol. 27, no. 9, pp. 1471-1475, 2004.

[43] A. D. Patil, A. J. Freyer, D. S. Eggleston et al., "The inophyllums, novel inhibitors of HIV-1 reverse transcriptase isolated from the Malaysian tree, Calophyllum inophyllum Linn," Journal of Medicinal Chemistry, vol. 36, no. 26, pp. 4131-4138, 1993.

[44] H. Dharmaratne, W. Wanigasekera, E. Mata-Greenwood, and J. Pezzuto, "Inhibition of human immunodeficiency virus type 1 reverse transcriptase activity by cordatolides isolated fromCalophyllum cordato-oblongum," Planta Medica, vol. 64, no. 05, pp. 460-461, 1998.

[45] H. R. W. Dharmaratne, G. T. Tan, G. P. K. Marasinghe, and J. M. Pezzuto, "Inhibition of HIV-1 reverse transcriptase and HIV-1 replication by Calophyllum coumarins and xanthones," Planta Medica, vol. 68, no. 1, pp. 86-87, 2002.

[46] E. Kudo, M. Taura, K. Matsuda et al., "Inhibition of HIV-1 replication by a tricyclic coumarin GUT-70 in acutely and 
chronically infected cells," Bioorganic \& Medicinal Chemistry Letters, vol. 23, no. 3, pp. 606-609, 2013.

[47] P. Zhou, Y. Takaishi, H. Duan et al., "Coumarins and bicoumarin from Ferula sumbul: anti-HIV activity and inhibition of cytokine release," Phytochemistry, vol. 53, no. 6, pp. 689-697, 2000.

[48] N. Marquez, R. Sancho, L. M. Bedoya et al., "Mesuol, a natural occurring 4-phenylcoumarin, inhibits HIV-1 replication by targeting the NF-kappaB pathway," Antiviral Research, vol. 66, no. 2-3, pp. 137-145, 2005.

[49] Q. Wang, Z. Ding, J. Liu, and Y. Zheng, "Xanthohumol, a novel anti-HIV-1 agent purified from Hops Humulus lupulus," Antiviral Research, vol. 64, no. 3, pp. 189-194, 2004.

[50] D. C. Rowley, M. S. T. Hansen, D. Rhodes et al., "Thalassiolins A-C: new marine-derived inhibitors of HIV cDNA integrase," Bioorganic \& Medicinal Chemistry, vol. 10, no. 11, pp. 3619-3625, 2002.

[51] N. Mahmood, C. Pizza, R. Aquino et al., "Inhibition of HIV infection by flavanoids," Antiviral Research, vol. 22, no. 2-3, pp. 189-199, 1993.

[52] S. Li, T. Hattori, and E. N. Kodama, "Epigallocatechin gallate inhibits the HIV reverse transcription step," Antiviral Chemistry and Chemotherapy, vol. 21, no. 6, pp. 239-243, 2011.

[53] K. Kitamura, M. Honda, H. Yoshizaki et al., "Baicalin, an inhibitor of HIV-1 production in vitro," Antiviral Research, vol. 37, no. 2, pp. 131-140, 1998.

[54] B. Q. Li, T. Fu, Y. Dongyan, J. A. Mikovits, F. W. Ruscetti, and J. M. Wang, "Flavonoid baicalin inhibits HIV-1 infection at the level of viral entry," Biochemical and Biophysical Research Communications, vol. 276, no. 2, pp. 534-538, 2000.

[55] S. Pasetto, V. Pardi, and R. M. Murata, "Anti-HIV-1 activity of flavonoid myricetin on HIV-1 infection in a dual-chamber in vitro model," PLoS One, vol. 9, no. 12, Article ID e115323, 2014.

[56] P. Chaniad, C. Wattanapiromsakul, S. Pianwanit, and S. Tewtrakul, "Anti-HIV-1 integrase compounds fromDioscorea bulbiferaand molecular docking study," Pharmaceutical Biology, vol. 54, no. 6, pp. 1077-1085, 2016.

[57] J. T. Ortega, A. I. Suarez, M. L. Serrano, J. Baptista, F. H. Pujol, and H. R. Rangel, "The role of the glycosyl moiety of myricetin derivatives in anti-HIV-1 activity in vitro," AIDS Research and Therapy, vol. 14, no. 1, 57 pages, 2017.

[58] A. Mazumder, K. Raghavan, J. Weinstein, K. W. Kohn, and Y. Pommier, "Inhibition of human immunodeficiency virus type-1 integrase by curcumin," Biochemical Pharmacology, vol. 49, no. 8, pp. 1165-1170, 1995.

[59] A. Mazumder, N. Neamati, S. Sunder et al., "Curcumin analogs with altered potencies against HIV-1 integrase as probes for biochemical mechanisms of drug action," Journal of Medicinal Chemistry, vol. 40, no. 19, pp. 30573063, 1997.

[60] N. Kumari, A. A. Kulkarni, X. Lin et al., "Inhibition of HIV-1 by curcumin A, a novel curcumin analog," Drug Design, Development and Therapy, vol. 9, pp. 5051-5060, 2015.

[61] R. A. Reinke, D. J. Lee, B. R. McDougall et al., "L-chicoric acid inhibits human immunodeficiency virus type 1 integration in vivo and is a noncompetitive but reversible inhibitor of HIV-1 integrase in vitro," Virology, vol. 326, no. 2, pp. 203-219, 2004.

[62] Y.-J. Zou, H.-X. Wang, T.-B. Ng, C.-Y. Huang, and J.-X. Zhang, "Purification and characterization of a novel laccase from the edible mushroom Hericium coralloides," The Journal of Microbiology, vol. 50, no. 1, pp. 72-78, 2012.
[63] H. X. Wang and T. B. Ng, "A new laccase from dried fruiting bodies of the monkey head mushroom Hericium erinaceum," Biochemical and Biophysical Research Communications, vol. 322, no. 1, pp. 17-21, 2004.

[64] M. Li, G. Zhang, H. Wang, and T. Ng, "Purification and characterization of a laccase from the edible wild mushroom Tricholoma mongolicum," Journal of Microbiology and Biotechnology, vol. 20, no. 7, pp. 1069-1076, 2010.

[65] H. X. Wang and T. B. Ng, "A laccase from the medicinal mushroom Ganoderma lucidum," Applied Microbiology and Biotechnology, vol. 72, no. 3, pp. 508-513, 2006.

[66] J. Sun, Q. J. Chen, Q. Q. Cao et al., "A laccase with antiproliferative and HIV-I reverse transcriptase inhibitory activities from the mycorrhizal fungus Agaricus placomyces," Journal of Biomedicine \& Biotechnology, vol. 2012, Article ID 736472, 12 pages, 2012.

[67] D. D. Hu, R. Y. Zhang, G. Q. Zhang, H. X. Wang, and T. B. Ng, "A laccase with antiproliferative activity against tumor cells from an edible mushroom, white common Agrocybe cylindracea," Phytomedicine, vol. 18, no. 5, pp. 374-379, 2011.

[68] H. X. Wang and T. B. Ng, "Purification of a novel lowmolecular-mass laccase with $\mathrm{HIV}-1$ reverse transcriptase inhibitory activity from the mushroom Tricholoma giganteum," Biochemical and Biophysical Research Communications, vol. 315, no. 2, pp. 450-454, 2004.

[69] S. Zhao, C. B. Rong, C. Kong et al., "A novel laccase with potent antiproliferative and HIV-1 reverse transcriptase inhibitory activities from mycelia of mushroom Coprinus comatus," BioMed Research International, vol. 2014, Article ID 417461, 8 pages, 2014.

[70] X. Wu, C. Huang, Q. Chen, H. Wang, and J. Zhang, "A novel laccase with inhibitory activity towards HIV-I reverse transcriptase and antiproliferative effects on tumor cells from the fermentation broth of mushroomPleurotus cornucopiae," Biomedical Chromatography, vol. 28, no. 4, pp. 548-553, 2014.

[71] J. H. Wong, T. B. Ng, Y. Jiang, F. Liu, S. C. Sze, and K. Y. Zhang, "Purification and characterization of a Laccase with inhibitory activity toward HIV-1 reverse transcriptase and tumor cells from an edible mushroom (Pleurotus cornucopiae)," Protein and Peptide Letters, vol. 17, no. 8, pp. 1040-1047, 2010.

[72] G.-Q. Zhang, Y.-F. Wang, X.-Q. Zhang, T. B. Ng, and H.-X. Wang, "Purification and characterization of a novel laccase from the edible mushroom Clitocybe maxima," Process Biochemistry, vol. 45, no. 5, pp. 627-633, 2010.

[73] L. Xu, H. Wang, and T. Ng, "A laccase with HIV-1 reverse transcriptase inhibitory activity from the broth of mycelial culture of the mushroom Lentinus tigrinus," BioMed Research International, vol. 2012, Article ID 536725, 7 pages, 2012.

[74] J. Sun, H. Wang, and T. B. Ng, "Isolation of a laccase with HIV-1 reverse transcriptase inhibitory activity from fresh fruiting bodies of the Lentinus edodes (Shiitake mushroom)," Indian Journal of Biochemistry \& Biophysics, vol. 48, no. 2, pp. 88-94, 2011.

[75] H. X. Wang and T. B. Ng, "Examination of lectins, polysaccharopeptide, polysaccharide, alkaloid, coumarin and trypsin inhibitors for inhibitory activity against human immunodeficiency virus reverse transcriptase and glycohydrolases," Planta Medica, vol. 67, no. 7, pp. 669-672, 2001.

[76] J. Balzarini, D. Schols, J. Neyts, E. Van Damme, W. Peumans, and E. De Clercq, "Alpha-(1-3)- and alpha-(1-6)-D-mannose-specific plant lectins are markedly inhibitory to human 
immunodeficiency virus and cytomegalovirus infections in vitro," Antimicrobial Agents and Chemotherapy, vol. 35, no. 3, pp. 410-416, 1991.

[77] J. Balzarini, J. Neyts, D. Schols et al., "The mannose-specific plant lectins from Cymbidium hybrid and Epipactis helleborine and the ( $\mathrm{N}$-acetylglucosamine)n-specific plant lectin from Urtica dioica are potent and selective inhibitors of human immunodeficiency virus and cytomegalovirus replication in vitro," Antiviral Research, vol. 18, no. 2, pp. 191-207, 1992.

[78] R. D. Charan, M. H. G. Munro, B. R. O’Keefe et al., "Isolation and characterization ofMyrianthus holstiiLectin, a potent HIV-1 inhibitory protein from the PlantMyrianthus holstii1," Journal of Natural Products, vol. 63, no. 8, pp. 1170-1174, 2000.

[79] G. Férir, D. Huskens, S. Noppen, L. M. I. Koharudin, A. M. Gronenborn, and D. Schols, "Broad anti-HIV activity of the Oscillatoria agardhii agglutinin homologue lectin family," Journal of Antimicrobial Chemotherapy, vol. 69, no. 10, pp. 2746-2758, 2014.

[80] T. Mori, B. R. O’Keefe, R. C. Sowder 2nd. et al., "Isolation and characterization of griffithsin, a novel HIV-inactivating protein, from the red alga Griffithsia sp," Journal of Biological Chemistry, vol. 280, no. 10, pp. 9345-9353, 2005.

[81] S. Zhao, Y. Zhao, S. Li et al., "A novel lectin with highly potent antiproliferative and HIV-1 reverse transcriptase inhibitory activities from the edible wild mushroom Russula delica," Glycoconjugate Journal, vol. 27, no. 2, pp. 259-265, 2010.

[82] Y. R. Li, Q. H. Liu, H. X. Wang, and T. B. Ng, "A novel lectin with potent antitumor, mitogenic and HIV-1 reverse transcriptase inhibitory activities from the edible mushroom Pleurotus citrinopileatus," Biochimica et Biophysica Acta (BBA)-General Subjects, vol. 1780, no. 1, pp. 51-57, 2008.

[83] C. H. Han, Q. H. Liu, T. B. Ng, and H. X. Wang, "A novel homodimeric lactose-binding lectin from the edible split gill medicinal mushroom Schizophyllum commune," Biochemical and Biophysical Research Communications, vol. 336, no. 1, pp. 252-257, 2005.

[84] G. Q. Zhang, J. Sun, H. X. Wang, and T. B. Ng, "A novel lectin with antiproliferative activity from the medicinal mushroom Pholiota adiposa," Acta Biochimica Polonica, vol. 56, no. 3, pp. 415-421, 2009.

[85] J. K. Zhao, H. X. Wang, and T. B. Ng, "Purification and characterization of a novel lectin from the toxic wild mushroom Inocybe umbrinella," Toxicon, vol. 53, no. 3, pp. 360-366, 2009.

[86] S. Zheng, C. Li, T. B. Ng, and H. X. Wang, "A lectin with mitogenic activity from the edible wild mushroom Boletus edulis," Process Biochemistry, vol. 42, no. 12, pp. 1620-1624, 2007.

[87] Y. Li, G. Zhang, T. B. Ng, and H. Wang, "A novel lectin with antiproliferative and HIV-1 reverse transcriptase inhibitory activities from dried fruiting bodies of the monkey head mushroom Hericium erinaceum," BioMed Research International, vol. 2010, Article ID 716515, 9 pages, 2010.

[88] H. Wang and T. B. Ng, "Isolation and characterization of velutin, a novel low-molecular-weight ribosome-inactivating protein from winter mushroom (Flammulina velutipes) fruiting bodies," Life Sciences, vol. 68, no. 18, pp. 2151-2158, 2001.

[89] S. K. Lam and T. B. Ng, "First simultaneous isolation of a ribosome inactivating protein and an antifungal protein from a mushroom (Lyophyllum shimeji) together with evidence for synergism of their antifungal effects," Archives of Biochemistry and Biophysics, vol. 393, no. 2, pp. 271-280, 2001.

[90] S. K. Lam and T. B. Ng, "Hypsin, a novel thermostable ribosome-inactivating protein with antifungal and antiproliferative activities from fruiting bodies of the edible mushroom Hypsizigus marmoreus," Biochemical and Biophysical Research Communications, vol. 285, no. 4, pp. 1071-1075, 2001.

[91] J. H. Wong, H. X. Wang, and T. B. Ng, "Marmorin, a new ribosome inactivating protein with antiproliferative and HIV-1 reverse transcriptase inhibitory activities from the mushroom Hypsizigus marmoreus," Applied Microbiology and Biotechnology, vol. 81, no. 4, pp. 669-674, 2008.

[92] Y.-M. Ng, Y. Yang, K.-H. Sze, X. Zhang, Y.-T. Zheng, and P.-C. Shaw, "Structural characterization and anti-HIV-1 activities of arginine/glutamate-rich polypeptide Luffin P1 from the seeds of sponge gourd (Luffa cylindrica)," Journal of Structural Biology, vol. 174, no. 1, pp. 164-172, 2011.

[93] I. Kaur, M. Puri, Z. Ahmed, F. P. Blanchet, B. Mangeat, and V. Piguet, "Inhibition of HIV-1 replication by balsamin, a ribosome inactivating protein of Momordica balsamina," PLoS One, vol. 8, no. 9, Article ID e73780, 2013.

[94] F. Rajamohan, T. K. Venkatachalam, J. D. Irvin, and F. M. Uckun, "Pokeweed antiviral protein isoforms PAP-I, PAP-II, and PAP-III depurinate RNA of human immunodeficiency virus (HIV)-1," Biochemical and Biophysical Research Communications, vol. 260, no. 2, pp. 453-458, 1999.

[95] T. Ichiba, P. J. Scheuer, M. Kelly-borges, and F. Pierce, "Three bromotyrosine derivatives, one terminating in an unprecedented diketocyclopentenylidene enamine," The Journal of Organic Chemistry, vol. 58, no. 15, pp. 4149-4150, 1993.

[96] D. Gochfeld, K. El Sayed, M. Yousaf et al., "Marine natural products as lead anti-HIV agents," Mini-Reviews in Medicinal Chemistry, vol. 3, no. 5, pp. 401-424, 2003.

[97] L. G. Gómez-Archila, W. Zapata, F. J. Díaz, M. T. Rugeles, E. Galeano, and A. Martínez, "Bromotyrosine derivatives from marine sponges inhibit the HIV-1 replication in vitro," Vitae, vol. 21, no. 2, pp. 114-125, 2014.

[98] S. A. Ross, J. D. Weete, R. F. Schinazi et al., "Mololipids, A new series of anti-HIV bromotyramine-derived compounds from a sponge of the order Verongida $\dagger$," Journal of Natural Products, vol. 63, no. 4, pp. 501-503, 2000.

[99] P. Yogeeswari and D. Sriram, "Betulinic acid and its derivatives: a review on their biological properties," Current Medicinal Chemistry, vol. 12, no. 6, pp. 657-666, 2005

[100] D. E. Martin, R. Blum, J. Wilton et al., "Safety and pharmacokinetics of Bevirimat (PA-457), a novel inhibitor of human immunodeficiency virus maturation, in healthy volunteers," Antimicrobial Agents and Chemotherapy, vol. 51, no. 9, pp. 3063-3066, 2007.

[101] D. E. Martin, R. Blum, J. Doto, H. Galbraith, and C. Ballow, "Multiple-dose pharmacokinetics and safety of bevirimat, a novel inhibitor of HIV Maturation, in healthy volunteers," Clinical Pharmacokinetics, vol. 46, no. 7, pp. 589-598, 2007.

[102] P. F. Smith, A. Ogundele, A. Forrest et al., "Phase I and II study of the safety, virologic effect, and pharmacokinetics/ pharmacodynamics of single-dose 3-O- $\left(3^{\prime}, 3^{\prime}\right.$-Dimethylsuccinyl)Betulinic acid (bevirimat) against human immunodeficiency virus infection," Antimicrobial Agents and Chemotherapy, vol. 51, no. 10, pp. 3574-3581, 2007.

[103] N. A. Margot, C. S. Gibbs, and M. D. Miller, "Phenotypic susceptibility to bevirimat in isolates from HIV-1-infected 
patients without prior exposure to bevirimat," Antimicrobial Agents and Chemotherapy, vol. 54, no. 6, pp. 2345-2353, 2010.

[104] A. Neyret, B. Gay, A. Cransac et al., "Insight into the mechanism of action of EP-39, a bevirimat derivative that inhibits HIV-1 maturation," Antiviral Research, vol. 164, pp. 162-175, 2019.

[105] B. Labrosse, O. Pleskoff, N. Sol, C. Jones, Y. Hénin, and M. Alizon, "Resistance to a drug blocking human immunodeficiency virus type 1 entry (RPR103611) is conferred by mutations in gp41," Journal of Virology, vol. 71, no. 11, pp. 8230-8236, 1997.

[106] B. Labrosse, C. Treboute, and M. Alizon, "Sensitivity to a nonpeptidic compound (RPR103611) blocking human immunodeficiency virus type 1 Env-mediated fusion depends on sequence and accessibility of the gp41 loop region," Journal of Virology, vol. 74, no. 5, pp. 2142-2150, 2000.

[107] I. Kostova, S. Raleva, P. Genova, and R. Argirova, "Structureactivity relationships of synthetic coumarins as HIV-1 inhibitors," Bioinorganic Chemistry and Applications, vol. 2006, Article ID 68274, 9 pages, 2006.

[108] B. Chenera, M. L. West, J. A. Finkelstein, and G. B. Dreyer', "Total synthesis of $( \pm)$-calanolide A, a non-nucleoside inhibitor of HIV-1 reverse transcriptase," The Journal of Organic Chemistry, vol. 58, no. 21, 1993.

[109] A. Kucherenko, M. T. Flavin, W. A. Boulanger et al., "Novel approach for synthesis of $( \pm)$-calanolide a and its anti-HIV activity," Tetrahedron Letters, vol. 36, no. 31, 1995.

[110] M. T. Flavin, "Synthesis, chromatographic resolution, and anti-human immunodeficiency virus activity of $( \pm)$-Calanolide A and its enantiomers," Journal of Medicinal Chemistry, vol. 39, no. 6, 1995.

[111] J. H. Cardellina, H. R. Bokesch, T. C. McKee, and M. R. Boyd, "Resolution and comparative anti-HIV evaluation of the enantiomers of calanolides A and B," Bioorganic \& Medicinal Chemistry Letters, vol. 5, no. 9, pp. 1011-1014, 1995.

[112] R. W. Buckheit Jr., E. L. White, V. Fliakas-Boltz et al., "Unique anti-human immunodeficiency virus activities of the nonnucleoside reverse transcriptase inhibitors calanolide A, costatolide, and dihydrocostatolide," Antimicrobial Agents and Chemotherapy, vol. 43, no. 8, pp. 1827-1834, 1999.

[113] R. Buckheit Jr., V. Fliakasboltz, W. Decker et al., "Comparative anti-HIV evaluation of diverse HIV-1-specific reverse transcriptase inhibitor-resistant virus isolates demonstrates the existence of distinct phenotypic subgroups," Antiviral Research, vol. 26, no. 2, pp. 117-132, 1995.

[114] J. C. García Zebadúa, G. A. Magos Guerrero, M. Mumbrú Massip et al., "Inhibition of HIV-1 reverse transcriptase, toxicological and chemical profile of Calophyllum brasiliense extracts from Chiapas, Mexico," Fitoterapia, vol. 82, no. 7, pp. 1027-1034, 2011.

[115] T. Creagh, J. L. Ruckle, D. T. Tolbert et al., "Safety and pharmacokinetics of single doses of (+)-calanolide a, a novel, naturally occurring nonnucleoside reverse transcriptase inhibitor, in healthy, human immunodeficiency virus-negative human subjects," Antimicrobial Agents and Chemotherapy, vol. 45, no. 5, pp. 1379-1386, 2001.

[116] D. A. Eiznhamer, T. Creagh, J. L. Ruckle et al., "Safety and pharmacokinetic profile of multiple escalating doses of (+)-calanolide A, a naturally occurring nonnucleoside reverse transcriptase inhibitor, in healthy HIV-negative volunteers," HIV Clinical Trials, vol. 3, no. 6, pp. 435-450, 2002.
[117] K. Matsuda, S. Hattori, R. Kariya et al., "Inhibition of HIV-1 entry by the tricyclic coumarin GUT-70 through the modification of membrane fluidity," Biochemical and Biophysical Research Communications, vol. 457, no. 3, pp. 288-294, 2015.

[118] H. Wang, Y. Liu, C. Huan et al., "NF- $\kappa$ B-Interacting long noncoding RNA regulates HIV-1 replication and latency by repressing NF- $\kappa \mathrm{B}$ signaling," Journal of Virology, vol. 94, no. $17,2020$.

[119] P. Bremner and M. Heinrich, "Natural products as targeted modulators of the nuclear factor-kappaB pathway," The Journal of Pharmacy and Pharmacology, vol. 54, no. 4, pp. 453-472, 2002.

[120] M. Karin, Y. Yamamoto, and Q. M. Wang, "The IKK NF- $\kappa$ B system: a treasure trove for drug development," Nature Reviews Drug Discovery, vol. 3, no. 1, pp. 17-26, 2004.

[121] R. Sancho, N. Márquez, M. Gómez-Gonzalo et al., "Imperatorin inhibits HIV-1 replication through an Sp1dependent pathway," Journal of Biological Chemistry, vol. 279, no. 36, pp. 37349-37359, 2004.

[122] E. Kozioł and K. Skalicka-Woźniak, "Imperatorin-pharmacological meaning and analytical clues: profound investigation," Phytochemistry Review, vol. 15, pp. 627-649, 2016.

[123] M. Deng, L. Xie, L. Zhong, Y. Liao, L. Liu, and X. Li, "Imperatorin: a review of its pharmacology, toxicity and pharmacokinetics," European Journal of Pharmacology, vol. 879, 2020.

[124] G. Casano, A. Dumètre, C. Pannecouque, S. Hutter, N. Azas, and M. Robin, "Anti-HIV and antiplasmodial activity of original flavonoid derivatives," Bioorganic \& Medicinal Chemistry, vol. 18, no. 16, pp. 6012-6023, 2010.

[125] T. P. T. Cushnie and A. J. Lamb, "Antimicrobial activity of flavonoids," International Journal of Antimicrobial Agents, vol. 26, no. 5, pp. 343-356, 2005.

[126] X. Zhao, K. Jiang, B. Liang, and X. Huang, "Anticancer effect of xanthohumol induces growth inhibition and apoptosis of human liver cancer through NF- $\kappa \mathrm{B} / \mathrm{p} 53$-apoptosis signaling pathway," Oncology Reports, vol. 35, no. 2, pp. 669-675, 2016.

[127] B. W. Vanhoecke, F. Delporte, E. Van Braeckel et al., "A safety study of oral tangeretin and xanthohumol administration to laboratory mice," Vivo, vol. 19, no. 1, pp. 103-107, 2005.

[128] K. Yamaguchi, M. Honda, H. Ikigai, Y. Hara, and T. Shimamura, "Inhibitory effects of (-)-epigallocatechin gallate on the life cycle of human immunodeficiency virus type 1 (HIV-1)," Antiviral Research, vol. 53, no. 1, pp. 19-34, 2002.

[129] K. Kawai, N. H. Tsuno, J. Kitayama et al., "Epigallocatechin gallate, the main component of tea polyphenol, binds to CD4 and interferes with gp120 binding," Journal of Allergy and Clinical Immunology, vol. 112, no. 5, pp. 951-957, 2003.

[130] C. L. Nance, E. B. Siwak, and W. T. Shearer, "Preclinical development of the green tea catechin, epigallocatechin gallate, as an HIV-1 therapy," Journal of Allergy and Clinical Immunology, vol. 123, no. 2, pp. 459-465, 2009.

[131] P. Anand, A. B. Kunnumakkara, R. A. Newman, and B. B. Aggarwal, "Bioavailability of curcumin: problems and promises," Molecular Pharmaceutics, vol. 4, no. 6, pp. 807-818, 2007.

[132] C. J. Li, L. J. Zhang, B. J. Dezube, C. S. Crumpacker, and A. B. Pardee, "Three inhibitors of type 1 human immunodeficiency virus long terminal repeat-directed gene expression and virus replication," Proceedings of the National Academy of Sciences, vol. 90, no. 5, pp. 1839-1842, 1993. 
[133] A. Ali and A. C. Banerjea, "Curcumin inhibits HIV-1 by promoting Tat protein degradation," Scientific Reports, vol. 627539 pages, 2016.

[134] A. L. Cheng, C. H. Hsu, J. K. Lin et al., "Phase I clinical trial of curcumin, a chemopreventive agent, in patients with highrisk or pre-malignant lesions," Anticancer Research, vol. 21, no. 4b, pp. 2895-2900, 2001.

[135] G. Shoba, D. Joy, T. Joseph, M. Majeed, R. Rajendran, and P. Srinivas, "Influence of piperine on the pharmacokinetics of curcumin in animals and human volunteers," Planta Medica, vol. 64, no. 4, pp. 353-356, 1998.

[136] P. Baldrian, "Fungal laccases-occurrence and properties," FEMS Microbiology Reviews, vol. 30, no. 2, pp. 215-242, 2006.

[137] P. Giardina, V. Faraco, C. Pezzella, A. Piscitelli, S. Vanhulle, and G. Sannia, "Laccases: a never-ending story," Cellular and Molecular Life Sciences, vol. 67, no. 3, pp. 369-385, 2010.

[138] M. Böttcher and F. Grosse, "HIV-1 protease inhibits its homologous reverse transcriptase by protein-protein interaction," Nucleic Acids Research, vol. 25, pp. 1709-1714, 1997.

[139] T. B. Ng and H. X. Wang, "A homodimeric laccase with unique characteristics from the yellow mushroom Cantharellus cibarius," Biochemical and Biophysical Research Communications, vol. 313, no. 1, pp. 37-41, 2004.

[140] H. X. Wang and T. B. Ng, "A novel laccase with fair thermostability from the edible wild mushroom (Albatrella dispansus)," Biochemical and Biophysical Research Communications, vol. 319, no. 2, pp. 381-385, 2004.

[141] A. E. Franco Molano and E. Uribe- Calle, "Hongos agricales y boletales de Colombia," Biota Colombiana, vol. 1, no. 1, pp. 25-43, 2000.

[142] C. Arboleda, A. I. Mejía, A. E. Franco-Molano, G. A. Jiménez, and J. Pm, "Autochthonous white rot fungi from the tropical forest of Colombia for dye decolourisation and ligninolytic enzymes production," Sydowia, vol. 60, no. 2, pp. 165-180, 2008.

[143] A. Ruiz and A. Varela, "Nuevos registros de Aphyllophorales (Basidiomicota) en bosque montano húmedo y de niebla de Colombia," Caldasia, vol. 28, no. 2, pp. 259-266, 2006.

[144] L. Flórez-sampedro, W. Zapata, W. Zapata et al., "In vitro anti-HIV-1 activity of the enzymatic extract enriched with laccase produced by the fungi ganoderma sp. and lentinus sp," Revista Vitae, vol. 23, no. 2, pp. 109-118, 2016.

[145] R. Goldstein Ijh, M. Monsigny, T. Osawa, and N. Sharon, "What should be called a lectin?" Nature, vol. 285, no. 66, 1980.

[146] H. Wang, T. B. Ng, and V. E. C. Ooi, "Lectins from mushrooms," Mycological Research, vol. 102, no. 8, pp. 897-906, 1998.

[147] J. Guillot and G. Konska, "Lectins in higher fungi," Biochemical Systematics and Ecology, vol. 25, no. 3, pp. 203-230, 1997.

[148] H. X. Wang, T. B. Ng, W. K. Liu, V. E. Ooi, and S. T. Chang, "Isolation and characterization of two distinct lectins with antiproliferative activity from the cultured mycelium of the edible mushroom Tricholoma mongolicum," International Journal of Peptide and Protein Research, vol. 46, no. 6, pp. 508-513, 1995.

[149] P. H. K. Ngai and T. B. Ng, "Lentin, a novel and potent antifungal protein from shitake mushroom with inhibitory effects on activity of human immunodeficiency virus-1 reverse transcriptase and proliferation of leukemia cells," Life Sciences, vol. 73, no. 26, pp. 3363-3374, 2003.
[150] H. Wang, T. B. Ng, and Q. Liu, "Isolation of a new heterodimeric lectin with mitogenic activity from fruiting bodies of the mushroom Agrocybe cylindracea," Life Sciences, vol. 70, no. 8, pp. 877-885, 2002.

[151] Q.-B. She, T.-B. Ng, and W.-K. Liu, "A novel lectin with potent immunomodulatory activity isolated from both fruiting bodies and cultured mycelia of the edible MushroomVolvariella volvacea," Biochemical and Biophysical Research Communications, vol. 247, no. 1, pp. 106-111, 1998.

[152] S. Sueyoshi, T. Tsuji, and T. Osawa, "Purification and characterization of four isolectins of mushroom (Agaricus bisporus)," Biol Chem Hoppe Seyler, vol. 366, no. 3, pp. 213-221, 1985.

[153] S. Oguri, M. Yoshida, and Y. Nagata, "Isolation, crystallization, and characterization of a $16.5-\mathrm{kDa}$ protein from fruit bodies of a lectin-deficient strain ofPleurotus cornucopiae," Bioscience, Biotechnology, and Biochemistry, vol. 58, no. 3, pp. 502-506, 1994.

[154] T.-S. Vo and S.-K. Kim, "Potential anti-HIV agents from marine resources: an overview," Marine Drugs, vol. 8, no. 12, pp. 2871-2892, 2010.

[155] M. D. Swanson, H. C. Winter, I. J. Goldstein, and D. M. Markovitz, "A lectin isolated from bananas is a potent inhibitor of HIV replication," Journal of Biological Chemistry, vol. 285, no. 12, pp. 8646-8655, 2010.

[156] T. Mori, B. R. O’Keefe, R. C. Sowder 2nd. et al., "Isolation and characterization of griffithsin, a novel HIV-inactivating protein, from the red alga Griffithsia sp," Journal of Biological Chemistry, vol. 280, no. 10, pp. 9345-9353, 2004.

[157] K. B. Alexandre, E. S. Gray, B. E. Lambson et al., "Mannoserich glycosylation patterns on HIV-1 subtype C gp120 and sensitivity to the lectins, Griffithsin, Cyanovirin- $\mathrm{N}$ and Scytovirin," Virology, vol. 402, no. 1, pp. 187-196, 2010.

[158] P. Emau, B. Tian, B. R. O’keefe et al., "Griffithsin, a potent HIV entry inhibitor, is an excellent candidate for anti-HIV microbicide," Journal of Medical Primatology, vol. 36, no. 45, pp. 244-253, 2007.

[159] B. R. O’Keefe, F. Vojdani, V. Buffa et al., "Scaleable manufacture of HIV-1 entry inhibitor griffithsin and validation of its safety and efficacy as a topical microbicide component," Proceedings of the National Academy of Sciences, vol. 106, no. 15, pp. 6099-6104, 2009.

[160] J. C. Kouokam, D. Huskens, D. Schols et al., "Investigation of griffithsin's interactions with human cells confirms its outstanding safety and efficacy profile as a microbicide candidate," PLoS One, vol. 6, no. 8, Article ID e22635, 2011.

[161] C. Barton, J. C. Kouokam, A. B. Lasnik et al., "Activity of and effect of subcutaneous treatment with the broad-spectrum antiviral lectin griffithsin in two laboratory rodent models," Antimicrobial Agents and Chemotherapy, vol. 58, no. 1, pp. 120-127, 2014.

[162] G. Férir, K. E. Palmer, and D. Schols, "Synergistic activity profile of griffithsin in combination with tenofovir, maraviroc and enfuvirtide against HIV-1 clade C," Virology, vol. 417, no. 2, pp. 253-258, 2011.

[163] L. F. Kramzer, K. T. Hamorsky, P. W. Graebing et al., "Preformulation characterization of griffithsin, a biopharmaceutical candidate for HIV prevention," AAPS PharmSciTech, vol. 22, no. 3, 83 pages, 2021.

[164] G. Günaydın, G. Edfeldt, D. A. Garber et al., "Impact of Q-Griffithsin anti-HIV microbicide gel in non-human primates: in situ analyses of epithelial and immune cell markers in rectal mucosa," Scientific Reports, vol. 9, no. 1, 18120 pages, 2019. 
[165] K. R. Crakes, C. Herrera, J. L. Morgan et al., "Efficacy of silk fibroin biomaterial vehicle for in vivo mucosal delivery of Griffithsin and protection against HIV and SHIV infection ex vivo," Journal of the International AIDS Society, vol. 23, no. 10, Article ID e25628, 2020.

[166] F. Minooei, J. R. Fried, J. L. Fuqua, K. E. Palmer, and J. M. Steinbach-Rankins, "In vitro study on synergistic interactions between free and encapsulated Q-griffithsin and antiretrovirals against HIV-1 infection," International Journal of Nanomedicine, vol. 16, pp. 1189-1206, 2021.

[167] "Study to evaluate the safety of griffithsin in a carrageenan gel in healthy women clinicaltrials," 2021, https://clinicaltrials. gov/ct2/show/study/NCT02875119.

[168] "Griffithsin-based rectal microbicide for PREvention of viral ENTry,” 2021, https://clinicaltrials.gov/ct2/show/ NCT04032717.

[169] R. A. Collins, T. B. Ng, W. P. Fong, C. C. Wan, and H. W. Yeung, "A comparison of human immunodeficiency virus type 1 inhibition by partially purified aqueous extracts of Chinese medicinal herbs," Life Sciences, vol. 60, no. 23, pp. Pl345-PL351, 1997.

[170] Q.-Z. Yao, M. M. Yu, L. S. M. Ooi et al., "Isolation and characterization of a type 1 ribosome-inactivating protein from fruiting bodies of the edible mushroom (volvariella volvacea)," Journal of Agricultural and Food Chemistry, vol. 46 , no. 2 , pp. $788-792,1998$.

[171] T. Girbes, J. Ferreras, F. Arias, and F. Stirpe, "Description, distribution, activity and phylogenetic relationship of ribosome-inactivating proteins in plants, fungi and bacteria," Mini-Reviews in Medicinal Chemistry, vol. 4, no. 5, pp. 461-476, 2004.

[172] S. A. Kidwai, A. A. Ansari, and A. Salahuddin, "Effect of succinylation (3-carboxypropionylation) on the conformation and immunological activity of ovalbumin," Biochemical Journal, vol. 155, no. 1, pp. 171-180, 1976.

[173] P.-C. Shaw, K.-M. Lee, and K.-B. Wong, "Recent advances in trichosanthin, a ribosome-inactivating protein with multiple pharmacological properties," Toxicon, vol. 45, no. 6, pp. 683-689, 2005.

[174] M. S. McGrath, K. M. Hwang, S. E. Caldwell et al., "GLQ223: an inhibitor of human immunodeficiency virus replication in acutely and chronically infected cells of lymphocyte and mononuclear phagocyte lineage," Proceedings of the National Academy of Sciences, vol. 86, no. 8, pp. 2844-2848, 1989.

[175] Y.-Y. Wang, D.-Y. Ouyang, H. Huang, H. Chan, S.-C. Tam, and Y.-T. Zheng, "Enhanced apoptotic action of trichosanthin in HIV-1 infected cells," Biochemical and Biophysical Research Communications, vol. 331, no. 4, pp. 1075-1080, 2005.

[176] W.-L. Zhao, D. Feng, J. Wu, and S.-F. Sui, "Trichosanthin inhibits integration of human immunodeficiency virus type 1 through depurinating the long-terminal repeats," Molecular Biology Reports, vol. 37, no. 4, pp. 2093-2098, 2010.

[177] W. Zhao, D. Feng, S. Sun, T. Han, and S. Sui, "The anti-viral protein of trichosanthin penetrates into human immunodeficiency virus type 1," Acta Biochimica et Biophysica Sinica, vol. 42, no. 2, pp. 91-97, 2010.

[178] V. Byers, A. Levin, L. Waites et al., "A phase I/II study of trichostathin treatment of HIV desease," Current Science, vol. 4, no. 2, pp. 1189-1196, 1990.

[179] V. S. Byers, A. S. Levin, A. Malvino, L. Waites, R. A. Robins, and R. W. Baldwin, "A phase II study of effect of addition of trichosanthin to zidovudine in patients with HIV disease and failing antiretroviral agents," AIDS Research and Human Retroviruses, vol. 10, no. 4, pp. 413-420, 1994.

[180] J. O. Kahn, K. J. Gorelick, G. Gatti et al., "Safety, activity, and pharmacokinetics of GLQ223 in patients with AIDS and AIDS-related complex," Antimicrobial Agents and Chemotherapy, vol. 38, no. 2, pp. 260-267, 1994.

[181] J. M. Zarling, P. A. Moran, O. Haffar et al., "Inhibition of HIV replication by pokeweed antiviral protein targeted to CD4+ cells by monoclonal antibodies," Nature, vol. 347, no. 6288, pp. 92-95, 1990.

[182] J. M. Zarling, P. A. Moran, O. Haffar et al., "Inhibition of HIV-1 replication in seropositive patients' CD4+ T-cells by pokeweed antiviral protein-monoclonal antibody conjugates," International Journal of Immunopharmacology, vol. 13, no. 1, pp. 63-68, 1991.

[183] G. Krivdova and K. A. Hudak, "Pokeweed antiviral protein restores levels of cellular APOBEC3G during HIV-1 infection by depurinating Vif mRNA," Antiviral Research, vol. 122, pp. 51-54, 2015.

[184] M. H. Pastrana Restrepo, Síntesis de derivados clorados $y$ bromados de la l-tirosina y evaluación in vitro de sus actividades antiparasitarias, Universidad de Antioquia, Antioquia, Colombia, 2016.

[185] P. Ciminiello, C. Dell'Aversano, E. Fattorusso, S. Magno, L. Carrano, and M. Pansini, "Chemistry of Verongida sponges. VII bromocompounds from the caribbean sponge Aplysina archeri," Tetrahedron, vol. 52, no. 29, pp. 9863-9868, 1996. 